\title{
THE THIRTEENTH AMENDMENT AND THE LOST ORIGINS OF CIVIL RIGHTS
}

\author{
RisA L. GOLUBOFF $\dagger$
}

\begin{abstract}
For the fifteen years prior to the Supreme Court's 1954 decision in Brown v. Board of Education, "civil rights" did not refer to a unified, coherent category. Rather, the content of the term was open, changing, and contradictory. The lawyers of the Civil Rights Section of the Department of Justice, which was created in 1939, were among those thinking about, and experimenting with, different ways of practicing and framing civil rights in the 1940s. Their practice shows how, as the Great Depression faded and World War II loomed, the most prominent civil rights issues shifted from the labor arena to the rights of minorities, especially African Americans. Because of the doctrinal uncertainties that accompanied the demise of the Lochner era, the lawyers of the Civil Rights Section looked to Reconstruction for inspiration, constitutional authority, and federal power. As the Section's law-
\end{abstract}

Copyright (c) 2001 by Risa L. Goluboff.

$\dagger \quad$ Law Clerk to the Honorable Guido Calabresi, United States Court of Appeals for the Second Circuit, 2000-2001. B.A., Harvard University; M.A., Princeton University; J.D., Yale Law School; Law Clerk to the Honorable Stephen G. Breyer, Associate Justice, United States Supreme Court, 2001-2002. An earlier version of this article was presented at the 2000 Annual Meeting of the American Society for Legal History. The author thanks Bruce Ackerman, Ariela Dubler, Myriam Gilles, Bob Gordon, Dirk Hartog, Dan Rodgers, and Reva Siegel for the time and energy they gave to this project at various stages. She also thanks Dan Ernst, Owen Fiss, Willie Forbath, Jesse Furman, Michael Klarman, Christian McMillen, Gil Seinfeld, Katherine Stone, Mark Tushnet, Ted White, and John Witt for their helpful comments and suggestions. Finally, the author thanks Rich Schragger for everything.

Many of the sources cited within were obtained from archival records. NAACP archival sources are from the Papers of the NAACP, Peonage, Labor, and the New Deal, 1913-1939, with general editors John H. Bracey, Jr., and August Meier, part of the Black Studies Research Sources, Microfilms from Major Archival and Manuscript Collections (Part 10) or NAACP and Labor, 1940-1955 (Part 13 of the same series) (1990). Department of Justice archival sources are from the Department of Justice Project files, Record Group 60, National Archives and Records Administration. Unless noted as being on file with the Duke Law Journal, Library of Congress cites are to the sources' locations in the collection of the manuscript division. Department of Justice cites are to the sources' locations at the National Archives and Records Administration. 
yers explored the boundaries of their new authority, they emphasized enforcement of the Thirteenth Amendment and involuntary servitude statutes. They came to use the Thirteenth Amendment as a vehicle for attacking legal and economic coercion broadly defined.

This Article narrates the history of the Civil Rights Section and analyzes its practice as a moment in the creation of modern civil rights law. Emphasizing that the wartime turn to racial issues did not eliminate labor from the Section's civil rights practice, it describes the resonances between the Section's civil rights framework-and its uses of the Thirteenth Amendment in particular-and both Reconstruction era and New Deal notions of free labor. Viewed against the backdrop of a historical concern with labor and the mid-century realities of involuntary servitude, we can see in the Section's practice a framework for a labor-infused civil rights that has, for the most part, since been lost.

\section{TABLE OF CONTENTS}

Introduction

I. Defining Civil Rights in Depression and War

A. "The Crucial Struggle for Civil Liberty Today": Labor and the Creation of the Civil Rights Section

B. Political Pressures for Civil Rights Prominence in Wartime America: The Increasing Salience of Race

II. Openings and Inspirations: Looking to the Past for Federal Authority to Protect Civil Rights

A. Doctrinal Uncertainties in Wartime Civil Rights

B. "Exploring the Interstices of the Constitution, Searching for National Authority"

III. Rediscovering the Thirteenth Amendment

A. Peonage in the 1940s: "No Small Part of the Work of the Civil Rights Section".

B. The Thirteenth Amendment's Unique Advantages: Federal Jurisdiction and State Action.

C. Jurisdiction and Rights Consciousness as Feedback Loop 
IV. Reconfiguring the Thirteenth Amendment, Redefining Involuntary Servitude

A. From Peonage to Involuntary Servitude, from Policing Private Contracts to Vindicating Civil Rights

B. Broadening Involuntary Servitude I: Attacking Legal Obstacles

C. Broadening Involuntary Servitude II: Focusing on Social and Economic Conditions

V. The Civil Rights Section's Thirteenth Amendment

Practice in Historical Perspective

A. Reviving Free Labor for the Postwar Era ....................... 1669

B. The Convergence of the Thirteenth Amendment and the New Deal.

Conclusion: Race, Labor, and a Lost Civil Rights 1680

\section{INTRODUCTION}

The 1954 civil rights victory of Brown v. Board of Education ${ }^{1}$ is one of the most commonly told stories in American constitutional law: Thurgood Marshall and the National Association for the Advancement of Colored People (NAACP) ${ }^{2}$ heroically convinced a courageous Supreme Court to resurrect the Equal Protection Clause of the Fourteenth Amendment as a vehicle for racial progress after its half century of ignominy following Plessy v. Ferguson ${ }^{3}$ in $1896 .^{4}$ Yet

1. 347 U.S. 483 (1954)

2. In 1939, motivated principally by tax considerations, the NAACP separated out its legal activities into the NAACP Legal Defense and Education Fund, commonly called the Inc. Fund. MARK Tushnet, Making Civil Rights LAW 27 (1994). The activities of the NAACP and the Inc. Fund remained considerably intertwined until the mid-1950s. Id. (discussing how Marshall served as special counsel to the NAACP and stating that part of NAACP Executive Secretary Walter White's salary was paid by the Inc. Fund). Only in 1956 did they separate to a greater extent, partly because of IRS complications and partly because of differing agendas. Id. at 27,310 . For simplicity, I refer to the NAACP lawyers simply as the NAACP, even though the activities of the NAACP as a whole clearly extended well beyond litigation.

3. 163 U.S. 537 (1896).

4. See generally Richard KLUger, Simple Justice, at $\mathrm{x}$ (1976) (referring to the Brown decision as "the turning point in America's willingness to face the consequences of centuries of racial discrimination"); TUSHNET, supra note 2, at 27-28 (detailing the NAACP's lobbying efforts, during the 1930s, for a federal law against lynching). But see Derrick Bell, Brown v. Board of Education and the Interest-Convergence Dilemma, 93 HARV. L. REV. 518, 524-26 (1980) (arguing that the Brown decision resulted not from heroism but from a short-lived convergence of white and African American interests); Michael J. Klarman, Brown, Racial Change, and the Civil Rights Movement, 80 VA. L. REV. 7, 76 (1994) (arguing that the main consequence of 
this story is a partial one at best. It fails to recognize that during World War II and the years that followed, the concept of civil rights looked very different from the way it looked after Brown, from the way it looks today, and from the way it looked during the half century that preceded the war. In fact, at the time, "civil rights" did not refer to a unified, coherent category; the content of the term was open, changing, and contradictory, carrying resonances of the past as well as of several possible contending futures.

This confusion and uncertainty have remained invisible to constitutional scholars chiefly because of the scope of their inquiries. ${ }^{5}$ Scholars seem to have accepted unquestioningly that modern civil rights should be located in the Equal Protection Clause of the Fourteenth Amendment and the Commerce Clause, failing to examine how these rights came to be thus situated. While commentators largely have overlooked the period from 1939 to $1954,{ }^{6}$ I argue that it

Brown was a heightened defense of Jim Crow by white southerners, and that Brown led to racial progress only indirectly, in response to violence against African Americans); Kenneth W. Mack, Black Lawyering in the Early Twentieth Century: Race Leadership and the Markers of Professional Authority 2-3 (2000) (unpublished manuscript, on file with the Duke Law Journal) (discussing the ways in which African American lawyers at mid-century were concerned not only with civil rights litigation but also with enhancing their professional standing)

5. A few scholars have begun to explore alternative origins and conceptions of civil rights in the second half of the twentieth century. See William E. Nelson, The Legalist REFORMATION: LAw, Politics, AND IDEOLOGY IN NEW York, 1920-1980 (forthcoming 2001) (discussing the development of civil rights in New York as growing out of the integrationist efforts of white ethnic and religious minorities); William E. Forbath, Caste, Class, and Equal Citizenship, 98 MiCH. L. REV. 1, 80 (1999) (presenting a vision of a "labor-based civil rights movement" that never realized its potential during and after the New Deal). Scholars since midcentury have referred to the years prior to Brown as the "passive period." John P. Frank, Court and Constitution: The Passive Period, 4 VAND. L. REV. 400, 403-04 (1951); see also Bruce Ackerman, Revolution on a Human Scale, 108 YALE L.J. 2279, 2334 (1999) (discussing the "tentative suggestions" of the Court during the late 1930s). See generally Barry Friedman, An Academic Obsession (The History of the Countermajoritarian Difficulty, Part III) 2, 8-16 (unpublished manuscript, on file with the Duke Law Journal) (discussing "the quiet years of the 1940s").

6. There are exceptions. See generally NELSON, supra note 5 (detailing the rise of New York's civil rights movement); HeRMAn PrITCHETt, THE RoOSEvelt CourT (1948) (studying the politics and values of the Roosevelt-era Court and their influence on that Court's decisions); TUSHNET, supra note 2, at 116-125 (discussing the NAACP's attack on segregated education from 1939-1945); MARK V. Tushnet, The NAACP's Legal Strategy Against SegREGATED EDUCATION, 1925-1950 (1987) (recounting the NAACP's campaign against segregated schools from the mid-1920s to its culmination in the early 1950s, including a discussion of the activities of the 1940s); Ackerman, supra note 5, at 2334 (describing the Supreme Court's jurisprudence during the 1930s as "tentative"); Daniel R. Ernst, The Ideal and the Actual in the State: Willard Hurst at the Board of Economic Warfare, in TOTAL WAR AND THE LAW: NEW PERSPECTIVES ON WORLD WAR II (Daniel R. Ernst \& Victor Jew eds., forthcoming 2001) (ex- 
was of critical importance to the subsequent development of civil rights. And while the Supreme Court and litigants like the NAACP usually have monopolized scholarly attention, I turn a lens toward constitutional experimentation in the executive branch. I argue that developments in the 1940s are crucial to understanding Brown's meaning and that the activities of the newly created Civil Rights Section of the Department of Justice are crucial to understanding emerging conceptions of civil rights in the 1940s.

This Article narrates the unfamiliar story of the "little and little known unit" of the Department of Justice, whose lawyers were among those thinking about, and experimenting with, different ways of practicing and framing civil rights in the 1940s. ${ }^{9}$ It shows how and why, with understandings of civil rights up for grabs, these lawyers

amining the effect of wartime administrative service on the future "dean of American legal historians") (on file with the Duke Law Journal); Forbath, supra note 5 (discussing the postNew Deal civil rights movement and its connections to the labor movement); Frank, supra note 5, at 400 (describing the years preceding Brown as the "passive period"); Martha Biondi, The Struggle for Black Equality in New York City, 1945-1955 (1997) (unpublished Ph.D. dissertation, Columbia University) (examining how the African American civil rights movement reshaped post-World War II New York) (on file with the Columbia University Library); Friedman, supra note 5 (arguing that the 1940s were a period of relative inaction by the Court).

7. See generally Gerald N. Rosenberg, The Hollow Hope: Can Courts Bring About Social CHANGE? (1993) (arguing that courts are poor instruments for social change). Ernst is again an exception. See generally Ernst, supra note 6.

8. Henry Putzel, Jr., Federal Civil Rights Enforcement: A Current Appraisal, 99 U. PA. L. REV. 439, 441-42 (1951).

9. Staff publications were abundant. E.g., Francis Biddle, Civil Rights in Times of Stress, 2 BILL RTS. REV. 13, 15 (1941) (outlining civil rights issues for America to consider while in the "twilight zone" directly before its entrance into World War II); Sydney Brodie, The FederallySecured Rights to Be Free from Bondage, 40 GEO. L.J. 367 (1952); Frank Coleman, Freedom from Fear on the Home Front, 29 IowA L. REV. 415, 415 (1944) (discussing how "[m]emories of the last war came back" when the incidence of lynching again seemed on the rise in World War II); Victor W. Rotnem, Civil Rights During War: The Role of the Federal Government, 29 IowA L. REV. 409, 409 (1944) [hereinafter Rotnem, Civil Rights During War] ("With the challenge to the ideals of democracy of the ideologies of fascism and communism, we who had long taken our democratic faith for granted have had a quickened sense of the values of a government based on the belief in the dignity and rights of the individual."); Victor W. Rotnem, Clarification of the Civil Rights' [sic] Statutes, 2 BILl RTS. REV. 252, 260 (1942) [hereinafter Rotnem, Clarification]; Victor W. Rotnem, Criminal Enforcement of Federal Civil Rights, LAW. GuILD REV., May 1942, at 18 [hereinafter Rotnem, Criminal Enforcement]; Victor W. Rotnem, The Federal Civil Right "Not to Be Lynched," 28 WASH. U. L.Q. 57 (1943) [hereinafter Rotnem, Right "Not to Be Lynched"]; Victor W. Rotnem, Federal Criminal Jurisdiction of Labor's Civil Rights, 2 LAW. GuILD ReV., Sept. 1942, at 21 [hereinafter Rotnem, Labor's Civil Rights]; Henry A. Schweinhaut, The Civil Liberties Section of the Department of Justice, 1 BILL RTS. REV. 206, 206 (1941). 
turned to the Thirteenth Amendment ${ }^{10}$ as a constitutional basis for civil rights protection. That amendment abolished slavery in 1865 and, by the start of the twentieth century, seemed to prohibit only a narrow type of involuntary servitude based on debt, called peonage. In the late 1940s and early 1950s, however, Civil Rights Section lawyers came to use the Thirteenth Amendment as a vehicle for instituting "free labor," broadly defined, and for prohibiting various kinds of legal and economic coercion.

Part I begins with the creation of the Civil Rights Section in 1939. It argues that although the Section originated out of 1930s concerns with labor rights, World War II dramatically changed the direction of its mandate. Wartime pressures for civil rights pushed government officials, lawyers, and scholars toward the protection of minorities. This shift stemmed from apprehension about contagious totalitarianism and fears of Japanese propaganda, overzealous wartime patriots, and increased African American organization and protest. This part concludes that for largely political reasons, civil rights protection of minorities in general, and of African Americans in particular, increased in prominence during the war. This does not mean that the civil rights of minorities were actually protected during the war, as the internment of Japanese Americans readily demonstrates. ${ }^{11}$

The contours of these rights were as yet undetermined within legal doctrine and institutions, however. Part II depicts the way in which the Civil Rights Section lawyers understood the possibilities for developing civil rights doctrine. The demise of the Lochner ${ }^{12}$ era with the judicial validation of the New Deal had created space for novel interpretations of individual rights and new doctrines addressing the role of government in protecting those rights. How large that space would be and what would fill it remained uncertain. For inspiration and authority, Section lawyers turned to a time before the Lochner era. They looked back to Reconstruction for both statutory and constitutional authority and for a more robust understanding of federal power.

10. The amendment reads in full: "Section 1. Neither slavery nor involuntary servitude, except as a punishment for crime whereof the party shall have been duly convicted, shall exist within the United States, or any place subject to their jurisdiction. Section 2. Congress shall have power to enforce this article by appropriate legislation." U.S. CONST., amend. XIII.

11. See infra note 82 .

12. Lochner v. New York, 198 U.S. 45 (1905). 
Part III discusses one aspect of the Reconstruction legacy that the Civil Rights Section revived. As the Section's lawyers explored the boundaries of their new authority, they emphasized enforcement of the Thirteenth Amendment and involuntary servitude statutes. Both as a result of doctrinal concerns about federal jurisdiction and the state action requirement and because of the heightened rights consciousness of many African Americans regarding the Thirteenth Amendment, what appeared earlier in the century to be a rather small set of harms redressable under that amendment took on far greater importance during World War II.

Because of the relative ease of invoking the Thirteenth Amendment, members of the Justice Department sought to expand the scope of its enforcement authority. Part IV follows the Department's prosecution of peonage and involuntary servitude cases through the 1940s and into the 1950s, showing how the meaning of the Thirteenth Amendment changed and expanded during that period. As complainants broadened their definitions of involuntary servitude, so too the Justice Department lawyers broadened the scope of their prosecutorial ambitions. Increasingly, the existence of abhorrent labor conditions-meager wages for back-breaking work accompanied by inhumane treatment-became the target of federal action under the Thirteenth Amendment.

Part V analyzes the Civil Rights Section's practice as a moment in the creation of modern civil rights. It emphasizes that the wartime turn to racial issues did not eliminate labor from the Section's civil rights practice. It shows the importance of labor concerns to that practice and describes the resonance between the Section's civil rights framework and both Reconstruction era and New Deal notions of free labor. This part argues that the Section's use of the Thirteenth Amendment enabled it to combine the past with the present, to link long-standing ideas about free labor with contemporary forms of coerced labor, and to parallel New Deal transformations in labor rights with broadening definitions of involuntary servitude. Finally, the Conclusion suggests that in the Department of Justice's Thirteenth Amendment practice-viewed against the backdrop of a historical concern with labor and the mid-century realities of involuntary servitude-we can see a framework for a labor-infused civil rights that has, for the most part, since been lost. 


\section{DEFINING CIVIL RIgHTS IN DEPRESSION AND WAR}

\section{A. "The Crucial Struggle for Civil Liberty Today": Labor and the Creation of the Civil Rights Section}

In 1939, Attorney General Frank Murphy created the Department of Justice's Civil Liberties Unit (quickly renamed the Civil Rights Section) in order to "pursue a program of vigilant action in the prosecution of infringement of these rights." ${ }^{\text {"13 }}$ He asserted that "an important function of the law enforcement branch of government is the aggressive protection of fundamental rights inherent in a free people." ${ }^{, 14}$

In creating the new unit, Murphy's first concerns were with the First Amendment and the rights of labor. ${ }^{15}$ If Murphy had been asked where in the Constitution one could find authority for vindicating

13. Robert K. Carr, Federal Protection of Civil Rights: Quest For a Sword 24 n.35 (1947). Although the terms "civil rights" and "civil liberties" were somewhat interchangeable at the time, to the extent that "civil liberties" referred to rights emanating from the Bill of Rights and "civil rights" to those linked to the Reconstruction era statutes and amendments, the name change of the unit appears symbolic of the shift in priorities I discuss below. I have no evidence, however, that such was the reason for the change. Apparently, the name changed in June 1941, because the chief of the unit, Victor Rotnem, feared public confusion of the unit with the American Civil Liberties Union (both shared the acronym "ACLU"). He also thought the change from "civil liberties" to "civil rights" minimized the "radical" sound of the Section. Id. For simplicity, I have used the terms "civil rights," "fundamental rights," and "individual rights" interchangeably. Part of the uncertainty during this period, however, was reflected in the lack of consensus about what those terms meant and how they were used. A "key word" analysis (d)10.7.9sc.3(e)-27.814.3("N(h)102")]T6(od,) 
civil rights, he likely would have pointed to the Bill of Rights. ${ }^{16}$ The only prosecution carried out in 1939, the first year of the unit's existence, for example, was to protect the First Amendment rights of a newspaper editor who published an exposé of gamblers and brothel operators. $^{17}$

With the Bill of Rights as his primary constitutional text, Murphy's definition of civil rights emphasized the rights of workers and labor organizers. As a liberal from Michigan, a "darling" of the American Civil Liberties Union (ACLU) ${ }^{18}$ a governor who negotiated with, rather than forcefully suppressed, sit-down strikers in the auto industry, Murphy was a man of his times. ${ }^{19}$ Many of the central questions of civil rights during the 1930 s were labor-related. ${ }^{20}$ The Great Depression brought economic concerns to the forefront of national politics. Labor unions and their activities garnered widespread public attention and federal action. First in the National Recovery Administration and later in the National Labor Relations Act and the Fair Labor Standards Act, labor was a major component of New Deal reforms and increased governmental authority. As one journalist wrote in 1936, "[t] he crucial struggle for civil liberty today is among tenant farmers and industrial workers, fighting for economic emancipation and security." 21

The most direct impetus for the new unit came from the La Follette Civil Liberties Committee, which, despite the breadth of its

16. See Jerold S. Auerbach, Labor and Liberty: The La Follette Committee AND THE NEW DEAL 217 (1966) ("Frank Murphy sought to extend this federal commitment to the entire Bill of Rights, for the benefit of all Americans. Depression problems made the exercise of federal power fashionable; the Bill of Rights was the residual beneficiary.").

17. FINE, supra note 15 , at 83.

18. Id. at 76 . During the 1930 s, the ACLU was closely affiliated with the labor movement and workers' rights. See SAMUEL WALKER, IN DEFENSE OF AMERICAN LiBERTIES: A HISTORY OF THE ACLU 96 (1990) (noting that "[1]abor issues dominated [ACLU President Roger] Baldwin's thinking").

19. FINE, supra note 15, at 76-98 (describing Murphy's involvement with labor unions and the La Follette Committee, as well as the activities of Murphy's new Civil Liberties Unit, later to be renamed the Civil Rights Section, which focused largely on labor); see also id. at 82 (stating that Murphy was "dedicated to the principle of justice for all").

20. Auerbach, supra note 16, at 75; John T. EllifF, The United STATES DePARTMENT OF JUSTICE AND INDIVIDUAL RIGHTS, 1937-1962, at 73 (1987) (quoting Roger Baldwin of the ACLU as stating that all other civil rights "are on the whole trifling in national effect compared with the fight for the rights of labor to organize").

21. AUERBACH, supra note 16, at 75 (quoting New Attacks Upon Liberties, Soc. ACTION, II, Jan. 10, 1936, at 19). 
name, addressed almost exclusively the rights of laborers. ${ }^{22}$ During the 1930s, the Justice Department's Criminal Division began to prosecute criminally violations of the National Labor Relations Act (NLRA) and other infringements of laborers' rights that grew out of La Follette Committee investigations. ${ }^{23}$ Most prominent among these cases were prosecutions of coal operators who prevented unions from organizing workers in Harlan County, Kentucky, and of "Boss" Hague in Jersey City, New Jersey, who made it virtually impossible to organize labor under his watch. ${ }^{24}$ Pointing to these scattered offshoots of the La Follette Committee, Lee Pressman, the general counsel of the Congress of Industrial Organizations (CIO), suggested the creation of a unit within the Department of Justice to "effectively protect the exercise of civil rights in the country." 25

Labor's centrality to 1930s ideas about civil rights thus played a major part in the creation of the Civil Rights Section. Although minorities' civil rights had long been championed by groups like the NAACP - which applauded the creation of the new unit-they constituted a minor chord on the national scene until World War II. ${ }^{26}$ With the advent of the war, however, the rights of minorities, particularly of African Americans, became far more central to the federal government's pursuit of civil rights authority. As the unit's lawyers went about pursuing their mandate of rights protection, they increasingly attacked racial inequalities and harms. ${ }^{27}$

22. Id. at 205-09 (demonstrating the strength of the ties between the new unit and the La Follette Committee); ELLIFF, supra note 20, at 66-67 (stating that pressures to create the unit came from organized labor, "Negro groups," and some in the legal profession, but finding that "the right of labor to organize and to advocate unionization ... provided the first occasions for the Justice Department to begin enforcement of the civil rights statutes"). As Civil Rights could encompass labor, race, and the Bill of Rights, unions, the NAACP, and the ACLU all applauded the creation of the new unit. See FINE, supra note 15, at 80.

23. FINE, supra note 15 , at 80.

24. Id. at 83-87; ELLIFF, supra note 20, at 74-86.

25. FINE, supra note 15, at 78-79 (quoting interview with Lee Pressman, General Counsel, Congress of Industrial Organizations (Nov. 12, 1964)).

26. Lynching especially was a prominent issue of concern to African Americans during the 1930s. See generally James Harmon Chadbourn, Lynching AND THE LAW 13-24 (1933) (analyzing the inability of the courts to protect individuals from lynching); WALTER T. HowARD, LYNCHINGS: EXTRALEGAL VIOLENCE IN FLORIDA DURING THE 1930s (1995) (giving a detailed history of mob violence in 1930s Florida).

27. That there was a general mid-century shift from labor to race as the central preoccupation of civil rights is commonplace in historical literature, but the shift is more often asserted than explained. See Alan Brinkley, The End of Reform: New DeAl Liberalism in RECESSION AND WAR 154, 160-70 (1995) (describing a shift in liberal thought from pro-statist to 


\section{B. Political Pressures for Civil Rights Prominence in Wartime America: The Increasing Salience of Race}

With the end of the 1930s and the Great Depression, and the beginning of the war, the spurs to civil rights protection changed dramatically. Unions and labor activities were regulated by the new federal administrative apparatus and were cabined by wartime regulation of strikes, wages, and production. Moreover, the war's domestic dimensions produced a whole new set of civil rights concerns. ${ }^{28}$ In particular, the rights of minorities of various kinds-especially racial and religious $^{29}$-became more salient. The growing perception that minorities' rights needed safeguarding had numerous sources: anxiety about the politically contagious totalitarianism of Europe, fears of repeating the repression and vigilantism of World War I, concern about Japanese propaganda directed at African Americans, and awareness of increased African American organization and protest.

Totalitarianism made a deep impression on American ideas about individual rights. ${ }^{30}$ Three new journals largely committed to

pro-individual rights, from concern about labor reform to concern about race relations); ELLIFF, supra note 20, at 180 (describing what he sees as an ebbing concern for labor issues in the Civil Rights Section during the 1940s); Gary Gerstle, The Protean Character of American Liberalism, 99 AM. HisT. REV. 1043, 1060-64 (1994) (describing how liberals realized that racial oppression continued despite economic advancement and so turned their attention to race); Peter J. Kellogg, Civil Rights Consciousness in the 1940s, 42 HISTORIAn 18, $22-25$ (1979) (describing a shift from concern about social and economic conditions to concern about white racism).

28. $C f$. Mary L. DudziaK, Cold War Civil Rights: Race and the IMAGe of AMERICAN DEMOCRACY (2000) (discussing the international pressures that brought civil rights to prominence during the Cold War).

29. For example, during a two-year period, the Supreme Court reversed itself on the right of Jehovah's Witnesses not to salute the United States flag in school. See W. Va. State Bd. of Educ. v. Barnette, 319 U.S. 624, 642 (1943) (overruling Minersville Sch. Dist. v. Gobitis, 310 U.S. $586(1940))$.

30. Legal scholars and historians who have written about the increased preoccupation of liberals and legal professionals with civil rights during and after World War II have focused largely on American reflections about totalitarianism in Europe. They have argued that the main inspiration for the new focus stemmed from attempts to differentiate the United States from totalitarian Europe through the protection of civil rights. See, e.g., BRINKLEY, supra note 27, at 154 (arguing that liberals began to believe that "[s]tatesmen ... could produce tyranny and oppression"). Gary Gerstle similarly argues that the increased wartime concern for civil rights stemmed from American liberals' confronting Hitler's racial and Stalin's economic policies in a self-reflective and self-critical manner. Gerstle, supra note 27, at 1071-73; see also Margaret Raymond, Rejecting Totalitarianism: Translating the Guarantees of Constitutional Criminal Procedure, 76 N.C. L. REV. 1193, 1196 (1998) (discussing the way in which post-World War II judges invoked the specter of totalitarianism in developing criminal procedure doctrine); Richard Primus, Note, A Brooding Omnipresence: Totalitarianism in Postwar Constitutional 
civil rights began publication at the beginning of the war: the Bill of Rights Review, published by the Civil Rights Committee of the American Bar Association; the Lawyers Guild Review; and the National Bar Journal, the journal of the all-African American National Bar Association. ${ }^{31}$ Articles in these journals, as well as many in mainstream law reviews, were preoccupied with threats to American democracy and individual civil rights. Hitler, Mussolini, and even Stalin menaced 'the 'American system,' of which the jealous safe-guarding of individual rights is so vital a part." ${ }^{, 32}$ Wartime Attorney General Francis Biddle noted, "One response in this country to the challenge of the ideals of democracy made by the new idealogies [sic] of Fascism and Communism has been a deepened realization of the values of a government based on a belief in the dignity and rights of man.",33

Thought, 106 YALE. L.J. 423, 424 (1996) (discussing how the "quest for an antitotalitarian formula" shaped post-World War II constitutional theory).

31. The National Bar Association was founded in 1925, in response to the exclusion of African Americans from the American Bar Association.

32. A New Venture and Its Purposes, 1 BILl RTs. REV. 3 , 3 (1940); see also Arthur Garfield Hays, Civil Liberties in War Time, 2 BILl RTs. Rev. 170, 171 (1942) (exhorting Americans to respect civil rights); John E. Mulder, The Canker of Intolerance, 2 BILL RTS. REV. 3, 4 (1941) ("The Europe of today is a horrible verification of [the] fact" that "[i]ntolerance breeds tyranny, and tyranny means that only one point of view may be uttered."). Although the word "totalitarianism" was first used by Walter Lippman to describe the electoral system of Mussolini's Italy and was not applied jointly to both Nazism and Communism until HANNAH ARENDT, THE ORIGINS OF TOTALITARIANISM (1951), these lawyers and academics made their own parallels when discussing threats to democracy and civil rights, even during the war. STEPHEN J. WhitFIELD, INTO THE DARK: HANNAH ARENDT AND TOTALITARIANISM 9-10 (1980).

33. Francis Biddle, Civil Rights and the Federal Law, Speech at Cornell University (Oct. 4, 1944) at 21 (on file with the Duke Law Journal); see also TUSHNET, supra note 2, at 70 (discussing the importance of similarity between totalitarianism and racism to Supreme Court justices during the war); Charles A. Beard, Message on the Launching of the "Bill of Rights Review," 1 BiLl RTS. REV. 39, 39 (1940) ("In an age when the retreat from reason threatens to become a rout, when naked force has been substituted for established law in great nations once deemed civilized, it is a happy omen that a journal dedicated to constitutional liberties appears under the auspices of the American Bar Association's Committee on the Bill of Rights."); David M. Bixby, The Roosevelt Court, Democratic Ideology, and Minority Rights: Another Look at United States v. Classic, 90 YALE L.J. 741, 761 (1981) (discussing the Supreme Court's increased attention to the civil rights of racial minorities as a result of its concern about totalitarianism); John W. Davis, Message on the Launching of the "Bill of Rights Review," 1 BILL RTs. REV. 43, 43 (1940):

So long as these guarantees [of liberty] are preserved in their full integrity we shall not have in this country Communism, Fascism, National Socialism, or any system by any other name under which the citizen becomes, in effect, a mere pawn in the hands of the State, or of any group of ambitious men who wield its power.

Rotnem, Civil Rights During War, supra note 9, at 409 ("With the challenge to the ideals of democracy of the ideologies of fascism and communism, we who had long taken our democratic 
Totalitarianism motivated concerns not only about civil rights generally, but also about involuntary servitude specifically. Several writers emphasized international concern about forced labor. In 1941, Bob Wirtz, secretary of the Chicago International Labor Defense, a communist-led popular front organization, ${ }^{34}$ peppered his policy statement for the newly formed Abolish Peonage Committee with references to "Nazi tyranny," "Hitlerism," and the "institution of human slavery [that] is an expression of Hitlerism in our country." 35 Political scientist Howard Devon Hamilton commented that "the revival of slavery on a large scale by the totalitarian regimes in the new form of slave labor camps for ethnic and political 'unregenerates' has shaken [the] comfortable thought" that "slavery and involuntary servitude [were] evils which were wiped out in the Nineteenth Century." 36

Other wartime pressures tended to reinforce worries about minorities' civil rights. Numerous articles warned against repeating the "mob rule" and government repression that had characterized the First World War. Espionage Act prosecutions of dissidents, pacifists, and radicals; attacks on German Americans; and the post-World War

faith for granted have had a quickened sense of the values of a government based on the belief in the dignity and rights of the individual."); Arthur T. Vanderbilt, Message on the Launching of the "Bill of Rights Review," 1 BILL RTS. REV. 41, 41 (1940) ("Until the relapse into barbarism that has characterized the last two decades in dictator countries, we calmly took the achievement of individual liberty for granted."). Looking back to the war, historian Alan Brinkley describes how liberals began to fear that "[h]owever serious the structural problems of the capitalist economy, a statist one might be worse than the disease.... They were defining their own nation increasingly as the antithesis of dictatorship." BRINKLEY, supra note 27, at 154-55.

34. The International Labor Defense (ILD) is most famous for its rivalry with the NAACP for control of the legal defense in the Scottsboro case in 1931. See generally DAN T. CARTER, SCOTTSBORO: A TRAGEDY OF THE AMERICAN SOUTH 66-67 (1969) (discussing the ILD's origins and the Scottsboro case); JAMES Goodman, StORIES OF SCOTTSBoro 82-84 (1994) (contrasting the ILD and NAACP as two entities with very different organizational approaches); Robin D.G. Kelley, Hammer and HoE: Alabama Communists During the Great DEPRESSION 78-91 (1990) (analyzing the ILD's involvement in intense racial and sexual disputes); Charles H. Martin, Communists and Blacks: The ILD and the Angelo Herndon Case, 64 J. NegRo Hist. 131, 132 (1979) (discussing the Scottsboro and Herndon cases that "propelled the Communist party into national and international notoriety as the self-professed defender of Afro-Americans against oppression").

35. Bob Wirtz, Policy Statement of Abolish Peonage Committee (n.d.) (on file with the Duke Law Journal).

36. Howard Devon Hamilton, The Legislative and Judicial History of the Thirteenth Amendment: What Is Not Involuntary Servitude, 10 NAT'L B.J. 7,77 (1952); see also TUSHNET, supra note 2, at 70 (discussing how as Roosevelt gained support from African Americans, the Supreme Court began to see them as a new constituency). 
I Red Scare and Palmer Raids (in which Attorney General Mitchell A. Palmer arrested thousands of alleged "Reds") had scared many Americans. Such incidents provoked the creation of the American Civil Liberties Union in $1920 .^{37}$ During World War II, memories of this repression spurred scholars and lawyers alike to vow to safeguard civil rights in the Second World War as they had not been safeguarded in the First. ${ }^{38}$ The editor of the Bill of Rights Review hoped "to profit by the experiences of World War I, [so] we can bend our efforts not to repeat our mistakes," ${ }^{39}$ but he lamented that the "lessons of the World War seem today forgotten." National Lawyers Guild, Edwin S. Smith commented, "In surveying the present civil liberties scene, it is well to remind ourselves of what happened to civil liberties during the Great War and its aftermath a generation ago." ${ }^{41}$ Smith depicted contemporaneous attacks on "democratic rights" as having taken "a direction which closely resembles the steps toward fascism followed in other countries." ${ }^{, 42}$ As

37. H.C. Peterson \& Gilbert C. Fite, Opponents of War, 1917-1918, at 138 (1957) (analyzing the ACLU's purpose in its early days); WILliam PRESTON, AliENS AND DisSENTERS: FEDERAL SUPPRESSION OF RADICALS, 1903-1933, at 262-72 (1966) (relating the ACLU's impact on Espionage Act prosecutions); WALKER, supra note 18, at 43-45 (discussing the "recently formed" ACLU's response to the Palmer Raids). For a general discussion of the post-World War I anticommunist hysteria, see RobERT K. MURRAY, RED SCARE: A STUDY IN NATIONAL HYSTERIA, 1919-1920 (1955).

38. E.g., Biddle, supra note 9, at 5; Coleman, supra note 9, at 415; Alexander Hamilton Frey, Securing American Democracy, 2 BILL RTS. REV. 165, 165 (1942) ("This war-torn generation may have substantially the same pious hopes as the preceding generation, but we are confident that we will avoid their post-war mistakes."); see also The Supreme Court and the Espionage Act of 1917, LAW. GUILD REV., June-July 1944, at 27 (highlighting a 1944 reversal of an Espionage Act conviction); The Writ of Habeas Corpus in War Time, LAW. GuILD REV., Jan.Feb. 1943, at 37 (discussing three contemporary Supreme Court cases).

39. John E. Mulder, Civil Liberty -1917-1942, 2 BILL RTS. REV. 83, 83 (1942).

40. John E. Mulder, Windmills of Hysteria, 1 BILL RTS. REV. 175, 175 (1941).

41. Edwin S. Smith, The Current Attack on Our Civil Liberties, LAw. GuILD Rev., June 1941 , at 5,6 .

42. Id. at 7. Roscoe Pound wrote in 1941:

We must distinguish between censorship to prevent military information ... from reaching the enemy, on the one hand, from, on the other hand, censorship to prevent criticism or discussion of governmental acts. The excuse for the latter is that such criticism and discussion encourages the enemy. But where a democracy is at war the enemy must know that a ruling majority is behind the war and can derive no real comfort from the critical publication of even a clamorous but politically powerless minority. It is not as if an autocrat, holding down a people with an iron hand, was waging war and any published dissent indicated he was losing his grip and faced with revolution at home

Roscoe Pound, Discussion and Criticism of the Operations of Government in Time of War, 1 BILL RTS. REV. 183, 183-84 (1941). 
Smith's comments suggest, the shadow of totalitarianism and the fear of descending into tyranny served to heighten this fear of repeating the past.

Anxiety about war propaganda at home and abroad intensified domestic attention to civil rights, especially with regard to African Americans. Public officials worried about the Axis Powers' attempts, most notably those of the Japanese, to point up contradictions between the United States' war for democracy and the failures of democracy at home. One federal official lamented Japanese and German radio broadcasts about the lynching of an African American man "[a]imed at the darker peoples of the world." ${ }^{, 43}$ He observed,

In Washington, officials learned of the lynching with heavy heart. It was, they knew, but the first of many gratuitous weapons of propaganda which America's "way of life" would deliver to our fascist enemies during the tragic years of war that lay ahead.... Stories of lynchings and police brutality against individuals of racial and religious minorities in the United States, [sic] would be welcome ammunition to the Axis enemies in their campaign to discredit the self appointed [sic] champions of the "Four Freedoms."

The Japanese used such incidents both to turn potential international allies against the United States and also to undermine the loyalty of African Americans to their government. ${ }^{45}$ According to Frank Coleman of the Justice Department, "[M] any considered the weakening of our prestige abroad as less serious than the impairment of morale at home." ${ }^{46}$ As African Americans' political and economic power increased, the consequences of popular discontent became of greater concern to the government, which feared that "many of our own citizens [will] become cynical and disillusioned about fighting on the seven seas and in every foreign land in the name of ideals which

43. Coleman, supra note 9 , at 415 .

44. Id. at $415-16$.

45. Although it is not clear how much propaganda Japan aimed at African Americans, the federal government's fears were not entirely groundless. See Sato Masaharu \& Barak Kushner, "Negro Propaganda Operations": Japan's Short-wave Radio Broadcasts for World War II Black Americans, 19 Hist. J. Film, RAdio \& TELEVISION 5, 10 (1999) (arguing that Japanese propaganda found a receptive audience in some radicalized sectors of the African American populace).

46. Coleman, supra note 9 , at 416 . 
even then were being trampled under foot at home." ${ }^{47}$ In the elections of 1936 and 1940, African Americans had voted overwhelmingly Democratic; they filled the ranks of the military; and they peopled the factories producing materials essential to the Allied defense. Moreover, African Americans did not hesitate to assert what power they possessed. While the Department of Justice witnessed "the general awakening of the nation to the importance of the protection of civil rights," willingness to countenance pervasive racial discrimination and inequality. When A. Phillip Randolph of the Brotherhood of Sleeping Car Porters threatened to march on Washington with one hundred thousand African Americans by his side, President Roosevelt issued an Executive Order creating the Fair Employment Practices Committee to appease him. ${ }^{49}$ In unions and in the military, ${ }^{50}$ on waterfronts

47. Id.; see also Biddle, supra note 33, at 23 ("[T] he denial of these rights—often merely of the right to live in peace-touches tragic irony when committed in the midst of a war fought to defend them elsewhere.").

48. Biddle, supra note 33, at 22; see also Coleman, supra note 9, at 419-29 (detailing the two key Supreme Court decisions in providing a foundation for continued and enhanced Department of Justice enforcement). The Civil Rights Section staff took some credit for the changes. As one unit chief argued, prior to 1939 "complaints that fundamental rights had been invaded were few in number. The country, it seems, was not 'civil liberties-conscious.' But upon the creation of the new section in the Department of Justice the mail indicated it was rapidly becoming so." Schweinhaut, supra note 9, at 206. Despite the limited jurisdiction of the unit, "hundreds of people ... immediately sought the aid and protection of the Department." Id.; see also Coleman, supra note 9, at 416 n.3 (describing a "jump[]" from 7000 complaints in 1941 to over 13,000 in 1942 "although there was no significant increase in actual violations").

49. See Herbert Garfinkel, When Negroes March: The March on Washington Movement in the Organizational Politics For FEPC (1959); Merl E. Reed, SeEdTime FOR THE MOdern Civil Rights Movement: The President's COMMITTEe on FaIR EMPloyment PRACTICE, 1941-1946 (1991); Louis Ruchames, RACE, Jobs, \& POLITICS: The STORY OF FEPC (1953).

50. See generally ERIC ARnesen, Brotherhoods of COlOR: Black RAILroad WORKERS AND THE STRUGGLE FOR EQUALITY (2000) (discussing the history of African American railway workers and their battles for civil and economic rights); NELSON LICHTENSTEIN, LABOR'S WAR AT HOME: THE CIO IN WORLD WAR II 124 (1982) (“[T]he upgrading of black workers proved far more explosive than that of white women, because it came as part of a larger program of civil rights action ....”); AUgust MEIER \& ELLIOTT RUDWICK, BLACK DETROIT AND THE RISE OF THE UAW 120 (1979) (describing the most "dramatic instances" of African American worker discontent); NEIL A. WYNN, THE AFro-AMERICAN AND THE SECOND WORLD WAR 68 (1993) (noting that outbreaks of racial violence between "servicemen of both races" during World War II "surpassed [that] of any previous period"); Robert Korstad \& Nelson Lichtenstein, Opportunities Found and Lost: Labor, Radicals, and the Early Civil Rights Movement, 75 J. AM. HIST. 786, 787 (1988) (noting that the half-million black workers who joined unions affiliated with the CIO in World War II "were in the vanguard of efforts to transform race relations"); John Modell et al., World War II in the Lives of Black Americans: 
and on streetcars, ${ }^{51}$ in organizations like the NAACP and the Communist party, ${ }^{52}$ African Americans became far more vocal during the war about their dissatisfaction with the racial status quo. ${ }^{53}$ In contrast to many African Americans' willingness to put aside their grievances for the sake of unity during World War I, ${ }^{54}$ World War II witnessed the simultaneous fight for democracy overseas and at home, in the "Double V" campaign. The possibility and reality of race riots, race-

Some Findings and an Interpretation, 76 J. AM. HIST. 838, 838 (1989) (“[F]or black men, the impact of military service influenced the structure of their aspirations in a way that contributed to the unwillingness to accept the prewar structure of racial dominance that characterized the nation.").

51. See Robin D.G. Kelley, Race Rebels: Culture, Politics, and the Black WORKING ClASS 58 (1994) (describing the resistance of African Americans on streetcars during World War II).

52. See generally WiLSON RECORD, RACE AND RADICALISM: THE NAACP AND THE COMMUNIST PARTY IN CONFLICT 84-131 (1964) (describing the NAACP's influence through labor movements during World War II); PATRICIA Sullivan, DAYS OF HOPE: RACE AND DEMOCRACY IN THE NEW DEAL ERA 133-68 (1996) (discussing race and civil rights issues generally in the World War II South and the NAACP's role in both).

53. For historical background on the increasing rights consciousness of African Americans during the war, see generally KELLEY, supra note 51 (discussing growing African American opposition to white supremacy in public spaces, including transportation, during World War II); SteVen F. LAwson, RunNing FOR FreEdom: Civil Rights and Black Politics in AMERICA SINCE 1941, at 1-28 (2d ed. 1991) (discussing World War II and the "origins of the Freedom Struggle"); Sullivan, supra note 52 (discussing the relationship between New Deal legislation and African American political action); PENNY M. VON ESCHEN, RACE AGAINST EMPIRE: BLACK AMERICANS AND ANTICOLONIALISM, 1937-1957 (1997) (discussing the politics surrounding African diaspora from the 1930s to the beginning of the Cold War); WYNN, supra note 50 (surveying the ways in which the war affected the political and cultural attitudes of African Americans); Richard M. Dalfiume, The "Forgotten Years" of the Negro Revolution, 55 J. AM. HIST. 90 (1968) (discussing how World War II acted as a stimulant to African American protest); Korstad \& Lichtenstein, supra note 50 (noting the impact of labor and radicals on the rights consciousness of African Americans during the war); Modell, supra note 50 (analyzing the economic, educational, and military service status of African Americans during the war); Lawrence R. Samuel, Dreaming in Black and White: African-American Patriotism and World War II Bonds, in Bonds of AfFection: Americans Define Their PATRiotism 191 (John Bodnar ed., 1996) (discussing the purchasing of war bonds by African Americans during World War II as a show of patriotism and loyalty); Harvard Sitkoff, Racial Militancy and Interracial Violence in the Second World War, 58 J. AM. HIST. 661 (1971) (describing the origins of the African American protest movement in the racial militancy stimulated by World War II).

54. W.E.B. DuBois, for example, urged African Americans to "close ranks" and set aside their grievances during World War I. See W.E.B. DuBois, Close Ranks!, 16 CRISIS 111 (1918), reprinted in W.E.B. DUBOIS, THE CRISIS WRITINGS 259 (1972).

55. The Pittsburgh Courier, an African American newspaper, coined the phrase "Double V" on February 14, 1942. See Sullivan, supra note 52, at 115-16, 135-36 (discussing the "Double V" for victory campaign); Samuel, supra note 53, at 192-93 (same). On this shift in attitudes generally, see Robert W. MUllen, Blacks in AMERICA's WARS: THE SHIFT IN AtTITUdes FROM THE REVOLUTIONARY WAR TO VIETNAM 54 (1973) ("Faced with rampant discrimination 
related strikes and walkouts, and African American defection from the Democratic party served to focus more national attention on racial equality than had been there previously.

In addition to the now familiar increase in organized African American protest activities during the war, African American discontent made itself known to the Justice Department directly, through complaints of civil rights violations. The majority of complaints the newly formed Civil Rights Section received concerned the rights of African Americans, mostly from the South. ${ }^{56}$ As these complaints reveal, northern, urban, industrial African American men were not the only ones who asserted themselves during World War II. So did others who rarely enter the historical literature. ${ }^{57}$ Southern African American men and women, unconnected to civil rights organizations, unions, or the military, vigorously protested involuntary servitude and peonage through all the avenues open to them. They wrote letters to the President and to First Lady Eleanor Roosevelt. ${ }^{58}$ They asked employers, ministers, and local leaders to help them. ${ }^{59}$ And they personally approached the Federal Bureau of Investigation (FBI), complained about their plight and the plights of their friends, neighbors, and relatives, and demanded federal action. ${ }^{60}$

Responding to these pleas, federal officials hoped the rapid and effective federal protection of civil rights would enhance both the United States' international standing and its domestic credibility. The

in employment, segregation, in the armed forces, and demeaning personal discrimination, Blacks reacted to the war not simply as Americans, but as Black Americans.").

56. See Biddle, supra note 33, at 23 (noting that the "great body" of these complaints deal with the general right to vote and other civil rights of African Americans); Victor W. Rotnem, Enforcement of Civil Rights, 3 NAT'L B.J. 1, 8 (1945) (noting that during the World War II era, most civil rights cases were brought by African Americans in the South). The staff appeared surprised that "[c]omplaints [came] not only from the victims and from the groups organized for the specific purpose of protecting civil liberties, but from fellow townsmen and neighbors of the victims." Biddle, supra note 33, at 22; see also Coleman, supra note 9, at 424 (discussing how "native Georgians" helped investigate civil rights violations).

57. Elsewhere, I have called them "the unorganized, the unaffiliated, the marginal." Risa L. Goluboff, "Won't You Please Help Me Get My Son Home”: Peonage, Patronage, and Protest in the World War II Urban South, 24 L. \& SOC. INQUIRY 777, 780 (1999) (discussing changes in the ways in which unorganized southern African Americans expressed their rights consciousness during the war).

58. See id. at 782-84 (describing various letters sent to the Department of Justice by African Americans complaining of peonage).

59. Id. at 791-96.

60. Id. at 796-98. 
Abolish Peonage Committee suggested in particular that "the unity of the American people today can be extended by a vigorous campaign to seek out and prosecute every violation of those United States statutes which make peonage a crime." ${ }^{11}$ Peonage cases "would strengthen the faith of millions of Negro people in the democracy for which they are loyally fighting against the aggressor fascist powers." ${ }^{62}$ The result of such pressures can be seen in Assistant Attorney General Wendell Berge's response to one U.S. Attorney regarding a peonage complaint from an African American man in Louisiana who was allegedly forced to work on the farm of a white man:

The matter complained of in the instant case is but one of many in which members of the Negro race have been the victims. Enemy propagandists have used similar episodes in international broadcasts to the colored race, saying that the democracies are insincere and that the enemy is their friend. There has been received from the President an instruction that lynching complaints shall be investigated as soon as possible; that the results of the investigation be made public in all instances, and the persons responsible for such lawless acts vigorously prosecuted. The Attorney General has requested that we expedite other cases relating to Negro victims. ${ }^{63}$

From the President to the Attorney General, to FBI agents and Justice Department lawyers alike, federal officials, particularly those

61. Wirtz, supra note 35 .

62. International Labor Defense, Unsigned Petition Letter to Francis Biddle (n.d.) (letter distributed to "one thousand prominent persons") (on file with the Duke Law Journal).

63. Memorandum from Wendell Berge, Assistant Attorney General, Department of Justice, to Clinton H. Barry, United States Attorney, Ft. Smith, Ark., Department of Justice (Aug. 8, 1942) (on file with the Duke Law Journal); see also Letter from Wendell Berge, Assistant Attorney General, Department of Justice, to Toxey Hall, United States Attorney, Jackson, Miss., Department of Justice (Aug. 10, 1942) (discussing same) (National Archives and Records Administration, Record Group 60, Department of Justice: 50-41-11); Letter from Wendell Berge, Assistant Attorney General, Department of Justice, to Steve M. King, United States Attorney, Beaumont, Tex., Department of Justice (Aug. 8, 1942) (discussing same) (National Archives and Records Administration, Record Group 60, Department of Justice: 50-74-4).

In at least one instance, successful prosecution led to precisely the kind of publicity the Department sought. After gaining a conviction in United States v. Skrobarcyzk, in which "a father and daughter... enslav[ed] a feeble-minded negro worker on their farm," the Corpus Christi Times editorialized, "The Skrobarcyzk trial and its conclusion undoubtedly will be said in the future to have given a decisive setback to the enemy propaganda machine in the United States." A Significant Trial, CORPus CHRISTI (TeX.) TIMES, Mar. 23, 1943 (on file with the Duke Law Journal). It went on to describe the insidious "urging ... among the negroes that their proper place in this conflict is with the yellow race." Id. But the trial made clear that "the negro, no matter what his station in life, has the protection of the laws of the land." Id. 
in the Civil Rights Section, were "seeking to draw the fire from Axis propaganda, which stem[med] from racial conflicts within the United States," by taking, winning, and publicizing cases with black victims. ${ }^{64}$ The federal government protected the civil rights of African Americans as "primarily a response to an awakened national conscience, demanding that the constitutional paper guarantees of individual freedom be made real in action. War had brought a pressure to substitute the technique of enforcement for that of promise." ${ }^{65}$

\section{OPENINGS AND INSPIRATIONS: LOOKING TO THE PAST FOR FEDERAL AUTHORITY TO PROTECT CIVIL RIGHTS}

Precipitated by the war, political pressures for civil rights turned the attention of the Civil Rights Section lawyers to the concerns of African Americans. What legal form those attentions would take was

64. Rotnem, Clarification, supra note 9, at 260. J. Edgar Hoover's response to the rumors about Japanese propaganda could not have differed more from Biddle's. The difference was rooted in part in politics and personal characteristics, but in part in their different institutional roles. Hoover instituted an investigation entitled "Foreign-Inspired Agitation Among the American Negroes," and sent his agents to American cities to root out any signs of black subversive activities or Japanese sympathy. Often, the very African Americans whose words provided testimony in Justice Department peonage cases also were the targets of FBI investigations. See generally THE FBI's RACON: RACIAL CONDITIONS IN THE UNITED STATES DURING WORLD WAR II (Robert A. Hill ed., 1995) (discussing Hoover's investigation). The differences between Hoover and the Civil Rights Section are apparent from a glance at the articles in a 1944 Iowa Law Review symposium on constitutional rights in wartime. Compare Rotnem, Civil Rights During War, supra note 9 (discussing federal jurisdiction over civil rights and advocating their use), and Coleman, supra note 9 (arguing for increased federal action in prosecuting lynchings and other mob actions), with J. Edgar Hoover, Alien Enemy Control, 29 IowA L. REV. 396 (1944) (discussing the need to monitor and be cautious of noncitizens during times of national emergency).

65. Coleman, supra note 9 , at 416 . As part of its agenda of taking peonage cases in order to publicize federal protection of African Americans, the Office of War Information issued many press releases during the war informing the public about the Justice Department's anti-peonage activities. E.g., Press Release, Office of War Information, Department of Justice (circa Nov. 27, 1942) (announcing arraignment of defendants in brutal Texas involuntary servitude prosecution) (on file with the Duke Law Journal); Press Release, Office of War Information, Department of Justice (Nov. 12, 1942) (announcing the indictment of a Florida man for unlawfully arresting "a Negro... for the purpose of holding him in involuntary servitude to work off an alleged debt") (on file with the Duke Law Journal); Press Release, Office of War Information, Department of Justice (Nov. 4, 1942) (announcing the indictment of a sheriff in Glades County, Florida, for removing inmates from the county jail and forcing them to work without pay on his farm) (on file with the Duke Law Journal); Press Release, Office of War Information, Department of Justice (Aug. 7, 1942) (describing the Department of Justice's investigation and prosecution of thirty-four peonage cases in seven southern states) (on file with the Duke Law Journal). 
far from settled, however. The fundamental doctrinal and constitutional uncertainties of the years following the rejection of Lochner provided the Section with space within which to experiment with possible frameworks for federal civil rights protection. Taking their cue from the Supreme Court, the Section's lawyers repudiated Lochnerera assumptions about individual rights and turned instead to an older source for federal authority: the Reconstruction constitutional amendments and civil rights statutes. ${ }^{66}$

66. I focus predominantly on the Section during Francis Biddle's tenure in office. Murphy left the Justice Department to join the Supreme Court less than one year after creating the new unit, and his successor, Robert Jackson, showed little interest in expanding federal power over civil rights as Attorney General. Peter Irons, Politics and Principle: An Assessment of the Roosevelt Record on Civil Rights and Liberties, 59 WASH. L. REV. 693, 708 n.69 (1984) (quoting a former Civil Rights Section lawyer as stating that Jackson "paid very little attention to our work and the old guard [in the Department] made it frustrating for us"); see also John T. Elliff, Aspects of Federal Civil Rights Enforcement: The Justice Department and the FBI, 1939-1964, in 5 Perspectives in AMERICAN History 605, 611-15 (Donald Fleming \& Bernard Bailyn eds., 1971) (discussing Jackson's approach to civil rights). Although as a Supreme Court Justice, Jackson would later author opinions in such individual rights cases as West Virginia State Board of Education v. Barnette, 319 U.S. 624, 642 (1943) (striking down a law requiring a flag salute in public schools only two years after the Supreme Court upheld such a law in Minersville School District v. Gobitis, 310 U.S. 586 (1940)) and the peonage case of Pollock v. Williams, 322 U.S. 4, 25 (1944) (striking down Florida's contract fraud statute as violating the Thirteenth Amendment), he did not generally favor intrusive executive branch action into civil rights. His civil rights staff was small and its jurisdiction severely limited, and he liked it that way. For a more detailed discussion of the limited jurisdiction of the unit and the effect of those limits on the definition of civil rights, see infra notes 112-31 and accompanying text. He believed that there was "an ever present danger of overstepping in investigations, of publicity tending to prejudge the accused, of wandering beyond the realm of criminal acts into that of unpopular opinion, of exceeding the proper bounds of Federal power." Robert H. Jackson, 1 BILL RTS. REV. 34, 35 (1940) (expressing the Attorney General's message in honor of the launching of the Bill of Rights Review). Jackson argued that the private bar was better equipped to handle the responsibility of protecting civil rights. He contrasted the eight lawyers of the Civil Rights Section with the 160,000-strong private bar in the United States: "Every failure of civil rights is at bottom a reflection on the legal profession.... If this bar is properly functioning it should be an adequate guarantee of the civil rights of every citizen." Id. at 34. Reminiscent of the prewar balance between public and private responsibilities and state and federal action, Jackson's ideological perspective hindered the Department from further pursuing its civil rights mandate.

In 1941, Attorney General Murphy's overall plan to vindicate something called civil rights found new support with a change in the personnel of the three key positions regarding civil rights in the Justice Department. Francis Biddle replaced Jackson, Wendell Berge replaced O. John Rogge as head of the Criminal Division, and Victor Rotnem replaced Henry Schweinhaut as head of the Civil Rights Section. In each instance, the new official was more active on civil rights than his predecessor, and the three men interacted more congenially than had the earlier trio. Elliff, supra, at 615. Francis Biddle named Rotnem to succeed Schweinhaut in the renamed Civil Rights Section in 1941. Id.; see also Coleman, supra note 9, at 419-29 (describing the revitalization of the Civil Rights Section under Attorney General Biddle). 


\section{A. Doctrinal Uncertainties in Wartime Civil Rights}

How to characterize and implement civil rights was an open question during the Second World War, as legal doctrine provided no definitive answer. In the late 1930s and early 1940s, established constitutional thought underwent dramatic change..$^{67}$ To the lawyers in the Civil Rights Section, the demise of "substantive due process"68 and New Deal-era changes in the relationships among government, individuals, and private industry ${ }^{69}$ allowed for novel interpretations of individual rights. New doctrines addressing the role of government in protecting those rights came about as well. ${ }^{70}$ As Frank Coleman, spe-

67. Despite extensive academic debates about the timing, causes, and legal and political significance of the end of the Lochner era, there is general consensus that change occurred. A major schism in the literature has been between those like BARRY CUSHMAN, RETHINKING the New Deal Court (1998); Merlo J. Pusey, Charles Evans Hughes (1951); Felix Frankfurter, Mr. Justice Roberts, 104 U. PenN. L. ReV. 311 (1955); Paul A. Freund, Charles Evans Hughes as Chief Justice, 81 HARV. L. REV. 4 (1967), who emphasize the cause of the change as occurring within legal doctrine, and those like EDWARD S. CORWIN, CONSTITUtional Revolution, Ltd. (1941); Robert G. McCloskey, The American Supreme Court (1st ed. 1960); Alpheus Thomas Mason, Harlan Fiske Stone: Pillar of the Law (1956); Alpheus Thomas Mason, The Supreme Court: Vehicle of ReVealed Truth or Power Group, 1930-1937 (1953); Benjamin F. Wright, The Growth of AMERICAN CONSTITUTIONAL LAW (1942), who emphasize external, political causes of the change. Bruce Ackerman has tried to move beyond this debate, providing an account of the transformation that incorporates both judicial reasoning in the Court's opinions and political concerns both within the Court and outside of it. See generally BRUCE ACKERMAn, We the PeOPle: Transformations (1998); Ackerman, supra note 5. For a general discussion of the debates, see Laura Kalman, Law, Politics, and the New Deal(s), 108 YALE L.J. 2165 (1999).

68. As G. Edward White has recently pointed out, "substantive due process" was a term created by critics of Lochner rather than a term used by Lochner-era judges themselves. G. Edward White, The Constitution and the New Deal 243-44 (2000) (noting that no Lochner-era judge used the term substantive due process).

69. See generally Cass R. Sunstein, Constitutionalism After the New Deal, 101 HARV. L. REV. 421 (1987) (describing shifts in federalism, checks and balances, and individual rights).

70. Despite the retrospective emphasis on the famous footnote four of United States $v$. Carolene Products Co., 304 U.S. 144, 152 n.4 (1938) (suggesting heightened scrutiny of legislation affecting "discrete and insular minorities"), as the primary response of American law to the fear of contagious totalitarianism, the footnote rarely appeared in wartime discussions of civil rights. For example, Carolene Products was not mentioned during the war in the three new journals largely committed to civil rights (Bill of Rights Review, Lawyers Guild Review, and the National Bar Journal). Such an absence demonstrates the extent to which the common narrative about the footnote is retrospective only. See Louis Lusky, Footnote Redux: A Carolene Products Reminiscence, 82 ColuM. L. REV. 1093, 1099 (1982) ("It should not be forgotten that, in the entire four years between the Footnote's appearance and the Gobitis decision, not one legal scholar had accepted the invitation it extended for further analysis and discussion."). For more information on these journals, see supra notes 31-32 and accompanying text. Even those, like the NAACP, who attempted to use the Equal Protection Clause on behalf of African Ameri- 
cial assistant to Attorney General Biddle, complained in 1944, "In the long years when the bar and bench were busily developing the great body of law which extends the protection of the Fourteenth Amendment to the property rights of corporations, these [civil rights statutes], for the most part lay dormant." ${ }^{, 71}$ As long as the courts viewed government power as limited by allegedly "free" contractual relations between individuals and private entities-as they had appeared to do during the Lochner era $^{72}$ - other conceptions of individual rights faced substantial barriers to gaining prominence. ${ }^{73}$

cans during the war did so without reference to the footnote, without a uniform vision of the ultimate outcome, and without certainty that they would eventually succeed. The apparent inevitability of the footnote's importance to civil rights jurisprudence is thus a product of recent scholarly construction.

71. Coleman, supra note 9, at 417-18.

72. A debate rages about the normative implications of the Lochner era, but the lawyers of the Civil Rights Section clearly adhered to the conventional vilification of the era. For that conventional view, see generally, for example, JOHN HART ELY, DEMOCRACY AND DISTRUST: A THEORY OF Judicial ReVIEW (1980) and ARNOLd M. PAUl, Conservative CRISIS AND THE RULE OF LAW: ATTITUDES OF BAR AND BENCH, 1887-1895 (1960). For recent revisions to that literature, see generally, for example, BRUCE ACKERMAN, We the PEOPLE: Foundations chs. 3 , 4 (1991); Howard Gillman, The Constitution Besieged: The Rise and Demise of Lochner Era Police Powers Jurisprudence (1993); Morton J. Horwitz, The TRANSFORMATION OF AMERICAN LAW, 1870-1960 (1977); Michael Les Benedict, Laissez-Faire and Liberty: A Re-Evaluation of the Meaning and Origins of Laissez-Faire Constitutionalism, 3 L. \& HIST. ReV. 293 (1985); Owen Fiss, Troubled Beginnings of the Modern State, 1888-1910, in 8 History OF THE Supreme COURT OF THE United STATES (1993); William E. Forbath, The Ambiguities of Free Labor: Labor and the Law in the Gilded Age, 1985 WIS. L. REV. 767 (1985); Harry Scheiber, American Federalism and the Diffusion of Power: Historical and Contemporary Perspectives, 9 U. TOL. L. REV. 619 (1978).

73. This is not to say that before 1937 contract rights were the only rights the Court validated, but that they were the most dominant. The Court did begin to address such issues as speech rights and rights of privacy. The early cases on freedom of speech include, in chronological order, Schenck v. United States, 249 U.S. 47, $52-53$ (1919) (holding that defendants could constitutionally be convicted of conspiring to cause the insubordination of the draft); Abrams $v$. United States, 250 U.S. 616, 623-24 (1919) (upholding the section of the Espionage Act that prohibited the urging of any curtailment of arms production with the intent to hinder the United States' war effort); Schaefer v. United States, 251 U.S. 466, 476-77 (1920) (upholding a conviction under the Espionage Act for willfully making and conveying false reports with the intent to promote the success of Germany in World War I); Gitlow v. New York, 268 U.S. 652, 668-70 (1925) (upholding a conviction under New York's "criminal anarchy" statute, which banned advocating the overthrow of the government by violent means); and Whitney v. California, 274 U.S. 357, 372 (1927) (affirming the legislature's right to forbid the knowing membership in any organization advocating the use of force to effect political change). Early privacy cases included Meyer v. Nebraska, 262 U.S. 390, 401-03 (1923) (striking down a state statute that prohibited the teaching of foreign languages to young children); and Pierce v. Society of Sisters, 268 U.S. 510, 534-35 (1925) (striking down a state law requiring children to attend public schools, rather than private or parochial ones). Moreover, as I discuss supra at notes 15-26 and accompanying text, 
Moreover, the end of the Lochner era transformed crucial balances of governmental power. The Supreme Court's celebrated opinions in the late New Deal-upholding the National Labor Relations Act, federal regulation of wages and hours, and other economic legislation ${ }^{74}$ - shifted power from the courts to the executive and legislative branches and thereby "unshackled" both state and federal governmental power. ${ }^{75}$ The Supreme Court previously had viewed government as an umpire distantly overseeing private contractual relations in which it was occasionally forced to intervene. The post-1937 Court, however, sanctioned a far more robust role for the federal government as protector and provider. It created space for the federal executive and legislative branches to put to use the power, bureaucratic complexity, and enormous number of employees they had gained during the New Deal and continued to gain during the war. ${ }^{76}$

counter-discourses of civil rights, focused largely around labor and the First Amendment, were prominent among many labor, left, and liberal lawyers and activists.

74. Steward Mach. Co. v. Davis, 301 U.S. 548, 578-98 (1937) (upholding the Social Security Act); NLRB v. Jones \& Laughlin Steel Corp., 301 U.S. 1, 49 (1937) (upholding the National Labor Relations Act); W. Coast Hotel Co. v. Parrish, 300 U.S. 379, 398-400 (1937) (upholding minimum wage law for women).

75. See Stephen Gardbaum, New Deal Constitutionalism and the Unshackling of the States, 64 U. CHI. L. REV. 483, 485-91 (1997) (discussing the simultaneous impact that the decisions of the Roosevelt-era Court had on both state and federal government power). Attorney General Francis Biddle contrasted the new regime favorably with the Lochner era, pleased that "the Supreme Court has generally not felt it necessary to yield to the temptation to substitute its views of federal-state relations for those of Congress where such [civil rights] statutes were before it for constitutional construction." Biddle, supra note 33, at 20.

76. Although the Supreme Court did not immediately act to clarify the meaning of individual rights, scholars frequently have focused on the small ways in which the judiciary was involved in the creation of new civil rights during the war. Bruce Ackerman, for example, has noted the "tentative suggestions" of the Court in cases like Palko v. Connecticut, 302 U.S. 319, 326-27 (1937) (discussing the concept of ordered liberty as the basis for incorporating some of the Bill of Rights through the Fourteenth Amendment), United States v. Carolene Products Co., 304 U.S. 144, 152 n.4 (1938) (suggesting that legislation affecting discrete and insular minorities or process rights be subject to stricter scrutiny than economic legislation), and West Virginia State Board of Education v. Barnette, 319 U.S. 624, 642 (1943) (overruling Minersville School District. v. Gobitis, 310 U.S. 586 (1940), and invalidating a mandatory flag salute in schools). Ackerman, supra note 5, at 2334. Mark Tushnet has narrated the NAACP's developing antisegregation litigation strategy while examining Thurgood Marshall's career there. See generally Tushnet, supra note 2; see also MELVIN I. UROFSKy, Division AND Discord: THE SUPREME COURT UNDER STONE AND VINSON, 1941-1953, at 85-113 (1997) (discussing the Supreme Court's individual rights cases in the 1940s). By remaining focused on the judiciary, instead of turning to the branches of government that gained power at the time, however, these and other scholars have missed important parts of the story, notably how executive power was exercised on behalf, rather than solely in abrogation, of minority rights. 
One loyal member of the Republican party tried to adapt to the changed circumstances of American politics during the war: "We cannot go back to a past which countenanced a widely-exploited labor, a greatly depressed agriculture, an irresponsible Wall Street; to a past which knew no old-age pensions, no unemployment insurance, no maximum hours and minimum wages."

The post-Lochner "period of acute social change" $" 78$ destroyed the old order without replacing it completely. No coherent model of civil rights existed during the war. Although the Bill of Rights Review was convinced "that a distinct field of law-that of civil rights-[was] emerging," "79 practitioners and scholars alike recognized that "the exact meaning of the general terms in which [civil rights statues] are couched was not clear." ${ }^{\prime 0}$ Even as late as 1952, the foreword to a treatise on political and civil rights in the United States could note, "Perhaps the best thing that can be said about the law in this field is that it is unsettled.... If ever there was a branch of law that was 'developing,' this is it." ${ }^{\prime \prime}$

The Civil Rights Section lawyers saw themselves taking considerable advantage of the dramatic doctrinal disjuncture of the late 1930s. The New Deal had demonstrated that the exercise of government power, rather than its restraint, might actually serve to protect the vulnerable. ${ }^{82}$ That transformation gave the government lawyers

77. C. Gordon Post, Civil Rights and the Role of the Republican Party in the Post-War World, 2 BILl RTS. REV. 201, 202 (1942).

78. Id. at 202. Bruce Ackerman has said of the post-Lochner period,

Only one thing was clear. If the Court were to reassert itself after the Great Depression, it could not do so through the same constitutional rhetoric with which it had rehabilitated itself after the Civil War. During the long period between Reconstruction and New Deal, the Court had risen to the heights of power by insisting upon the fundamental right of free men to pursue their private aims in a free market system. Yet it was precisely this ideological elixir ... that proved nearly fatal during the constitutional birth agony of the activist welfare state. If the Court were to build a new foundation for judicial review, it would need an entirely new constitutional rhetoric-one that self-consciously recognized that the era of laissez-faire capitalism had ended.

Bruce A. Ackerman, Beyond Carolene Products, 98 HARV. L. REV. 713, 714 (1985).

79. Civil Liberties-A Field of Law, 1 BILL RTs. REV. 7,7 (1940).

80. Coleman, supra note 9, at 417-18.

81. Robert M. Hutchins, Foreword to Political AND Civil Rights IN THE UNITED STATES, at iii (Thomas I. Emerson \& David Haber eds., 1952).

82. I am not arguing here that the government never violated individual rights. In light of Japanese internment, repression of alleged "subversives," and government discrimination of minorities in a host of circumstances, such a claim is untenable. I am, however, arguing that a counterforce arose during World War II, in which parts of the federal government also acted to protect individual rights. 
not only an opportunity to follow Murphy's call to "make a study of the provisions of the Constitution and Acts of Congress relating to civil rights, ${ }^{\not 3}$ but also room to improvise on the results of that study.

\section{B. "Exploring the Interstices of the Constitution, Searching for National Authority"}

With the present doctrinally open and the recent past repudiated, the Civil Rights Section lawyers looked to more distant history for their inspiration and authority. One contemporary commentator described how, in order to create a basis for the unit's authority, Biddle and his lawyers began "combing the statutes, ... exploring the interstices of the Constitution, searching for national authority." away from the Bill of Rights, the Section lawyers increasingly saw the Reconstruction amendments and statutes as "constitut[ing] the sole source of the power of the Federal Government to protect individual rights against encroachment by the States and, in some instances, by individuals. ${ }^{, 85}$ In doing so, as I will discuss further in Part V, the lawyers did not eliminate questions of labor altogether from their conception of civil rights. Rather, they integrated them into a practice that took as its basic texts the Reconstruction amendments and statutes. ${ }^{86}$

83. Schweinhaut, supra note 9, at 206.

84. Howard Devon Hamilton, The Legislative and Judicial History of the Thirteenth Amendment: The Inception of the Thirteenth Amendment, 9 NAT'L B.J. 26, 81-82 (1951).

85. Biddle, supra note 33, at 9. The three amendments ratified after the Civil War were the Thirteenth (abolishing slavery and involuntary servitude), the Fourteenth (conferring citizenship on former slaves and requiring states to provide due process and equal protection of the laws), and the Fifteenth (outlawing discrimination in voting based on race, color, or previous condition of servitude). U.S. CONST. amend. XIII-XV. The statutes Congress enacted included the Civil Rights Act of 1866, ch. 31, 14 Stat. 27 (1866), the Peonage Act of 1867, ch. 187, 14 Stat. 546 (1867), the Enforcement Act of 1870, ch. 114, 16 Stat. 140 (1870), the Ku Klux Klan Act of 1871, ch. 22, 17 Stat. 13 (1871), and the Civil Rights Act of 1875, ch. 114, 18 Stat. 335 (1875). Today, the remains of the Reconstruction statutes are codified at 42 U.S.C. $\S \S 1981,1982,1983$, 1985(3), 1986, and 1988 (1994), and the civil rights procedural statutes at 28 U.S.C. $\$ \S 1343,1443$ (1994). This Article focuses on the criminal sanctions for both peonage, codified at 18 U.S.C. $\S 1584$ (Supp. IV 1998), and the other civil rights laws, codified at 18 U.S.C. § 241 (1994 \& Supp. IV 1998), which prohibit conspiracies against civil rights by two or more persons, and 18 U.S.C. $\S 242$ (Supp. IV 1998), which prohibits the deprivation of rights under color of law. During the 1940s, the peonage statute was codified at 18 U.S.C. $\S 444$ (1946), section 241 was codified at 18 U.S.C. $§ 51$ (1946) (and was referred to as simply "the conspiracy statute"), and section 242 was codified at 18 U.S.C. $\$ 52$ (1946) (and was referred to as "the color of law statute").

86. In fact, the Department already had begun to use the Reconstruction criminal civil rights statutes in conjunction with New Deal labor legislation to protect the rights of workers in 
In their practice and their publications, the Civil Rights Section lawyers went about radically upending the constitutional understandings of the post-Reconstruction legal order. They adopted the early view of Justice Field that Reconstruction had, as Civil Rights Section Chief Victor Rotnem put it, "drastically altered the earlier balance of power between the states and the Federal government." ${ }^{87}$ Rotnem lamented the late-nineteenth century Supreme Court's inability to

contemplate the possibility of the drastic changes in balance which Congress asserted it intended to make effective through the three amendments and the four statutes. In a series of cases in which the vote was always that of a divided court, the meaning of the amendments and of the statutes was whittled down.... Congress' own theory of the scope of its powers under the 13th and 14th Amendments was rejected.

Attorney General Biddle contrasted the federalist balance struck at the Founding - when men taken by a "resentment and fear of government $"$ " ensured that federal power would be both less important than state power and purely negative in its protections of individual rights - with the post-Civil War federalism which invested affirmative protections in the national government. "The National Government rather than the States became at that time the proponent of liberal doctrine." ${ }^{, 90}$ In declaring that the "balance of State and Federal power was materially altered," ${ }^{91}$ Biddle found historical support for his aggressive federal program of civil rights: Federal power was not new during World War II; he was restoring it to the rightful place it had

the late 1930s. See AUERBACH, supra note 16, at 120-21 (recounting some successes of the Department of Justice in protecting the rights of workers); ELLIFF, supra note 20, at 74-86 (detailing how, "in the late 1930s the identification of labor rights with civil liberties added considerable force to the Justice Department's development of a positive civil rights program"); FINE, supra note 15, at 77-78 (noting that "[t]he failure of the Justice Department to secure a conviction in the Harlan County [coal operators] case on the basis of a Reconstruction era statute did not deter it from seeking to persuade another federal grand jury that [Jersey City Mayor] Frank Hague's [anti-union] regime had violated a civil rights law of similar vintage").

87. Rotnem, supra note 56, at 4.

88. Id. at 5 .

89. Biddle, supra note 33 , at 2 .

90. Id. at 4

91. Id. at 9 . 
briefly held, and then lost, during Reconstruction. ${ }^{92}$ The unit's "task was to reestablish [the statutes passed to protect civil rights during Reconstruction] as effective instruments for the protection of individual rights." ${ }^{, 3}$

With all of Reconstruction to draw on, no particular jurisprudential replacement for substantive due process seemed inevitable to the Civil Rights Section lawyers. A new, post-World War II understanding of civil rights therefore need not have come only from the Fourteenth Amendment. In fact, to a considerable extent, Section lawyers shied away from challenging Lochner-era Fourteenth Amendment doctrine. ${ }^{94}$ In the decades around the turn of the century, in cases like Plessy v. Ferguson, the Supreme Court depleted the power of the Equal Protection Clause of the Fourteenth Amendment in the name of a robust state police power: regulating race relations, and the relations between citizen and citizen generally, was a job for the states. ${ }^{95}$

92. Section lawyers did not explicitly, at least, model themselves after what was arguably the first experiment into federal protection of civil rights: the Freedmen's Bureau. Whether the Bureau actually protected the rights of the newly freed slaves or instead violated their rights in various ways has been the subject of much historical debate. See, e.g., LEON F. LITWACK, BEEN IN THE STORM So LONG 379-83 (1979) (arguing that although the Bureau was supposed to protect the freed slaves, it actually disciplined them in a variety of ways); AMY DRU STANLEY, From Bondage to Contract: Wage Labor, Marriage, and the Market IN THE AgE OF SLAVE EMANCIPATION 36-37 (1998) (discussing how the Bureau both recognized the freed slaves' right to liberty and also coerced them into labor contracts); THE FrEEDMEN's BUREAU AND Reconstruction, at ix (Paul A. Cimbala \& Randall M. Miller, eds. 1999) (compiling several works discussing various aspects of the Freedmen's Bureau and debating its effects).

93. Biddle, supra note 33, at 21; see also CARR, supra note 13, at 27-29 (discussing the Section's experimental use of the Reconstruction criminal civil rights statutes). According to one Civil Rights Section lawyer in the early 1950s, the unit could claim considerable success: "Before the Section came into existence, [18 U.S.C. § 242] was rarely employed; now a substantial body of law has developed, defining not only the statute itself, but the right protected thereunder and under the Fourteenth Amendment." Brodie, supra note 9, at 374 n.33. The difference in the number of peonage and involuntary servitude prosecutions was not as stark because the Department had prosecuted those cases prior to 1939, but Brodie emphasized that "the organization of the Section did have the effect of providing centralized enforcement resulting in greater coordination, efficiency, and methodization" of prosecutions of this type. Id. at 373-74. In addition, one NAACP staff person mused that peonage complaints were probably on the rise due to "the general pattern which is being adopted in southeastern Missouri to intimidate and deter farm laborers from leaving the area for more lucrative employment in industrial centers." Letter from Administrative Assistant, NAACP, to Victor Rotnem (May 27, 1943) (NAACP Papers, Library of Congress, Part II, Box B112).

94. See ElLIFF, supra note 20, at 259-64 (discussing the Section's reluctance to prosecute state actors for enforcing segregation).

95. See Fiss, supra note 72, at 352-85 (discussing Supreme Court jurisprudence around the time of the Plessy decision). 
As New Deal reforms and their judicial validation caused Lochner to fade, Plessy nonetheless remained good law.

Even as the Civil Rights Section lawyers saw themselves as "[p]ioneering in the field of theory as well as of action," tated, for both political and doctrinal reasons, to challenge Plessy. Politically, attacking the state apparatus that underpinned Jim Crow might have meant alienating Franklin Roosevelt's southern Democratic allies. Doctrinally, as I will discuss in Part III, the Section decided to try to expand positive precedents where possible, rather than challenge negative ones head on. These limitations, on strategy and on imagination, meant that even as the Section's lawyers selfconsciously set out to create something new, the past remained with them.

\section{REDISCOVERING THE THIRTEENTH AMENDMENT}

\section{A. Peonage in the 1940s: "No Small Part of the Work of the Civil Rights Section"}

When the lawyers of the Civil Rights Section explored the Reconstruction era for authority, they found the Thirteenth Amendment to be one of the most promising of the available "instruments for the protection of individual rights." ${ }^{, 97}$ Ratified at the end of the Civil War to abolish slavery, the scope of the Thirteenth Amendment vacillated widely between 1865 and 1939. Immediately after its passage, numerous courts recognized its expansive possibilities for establishing freedom and equality. ${ }^{98}$ According to legal scholar Jacobus tenBroek, writing in 1951, many Reconstruction congressmen thought that the Thirteenth Amendment alone could constitutionally sanction the

96. Coleman, supra note 9 , at 418 .

97. Biddle, supra note 33 , at 21.

98. See, e.g., In re Turner, 24 F. Cas. 337, 339 (C.C.D. Md. 1867) (No. 14,247) (holding the Civil Rights Act of 1866 constitutional pursuant to the Thirteenth Amendment and finding the apprenticeship of an African American to be involuntary servitude under the Thirteenth Amendment and in violation of the Civil Rights Act); United States v. Rhodes, 27 F. Cas. 785, 788 (C.C.D. Ky. 1866) (No. 16,151) (interpreting the Thirteenth Amendment broadly and holding the Civil Rights Act of 1866 constitutional pursuant to the Thirteenth Amendment); United States v. Morris, 125 F. 322, 325 (E.D. Ark. 1903) (quoting the expansive language of Rhodes and stating that "[t]he thirteenth amendment is a great extension of the powers of the national government"); Smith v. Moody, 26 Ind. 299, 307 (1866) (upholding the Civil Rights Act of 1866 pursuant to the Thirteenth Amendment). 
sweeping prohibitions of the Civil Rights Act of $1866 .^{99}$ During and after Reconstruction, however, the Supreme Court stepped back from the revolution in the federalist balance that such an expansive reading could have effected. In opinions like the Slaughter-House Cases ${ }^{100}$ and the Civil Rights Cases, ${ }^{101}$ the Court restricted the meanings of both the Thirteenth and the Fourteenth Amendments and minimized the role the federal government would play in protecting individual rights. ${ }^{102}$

By the turn of the twentieth century, the Supreme Court read the Thirteenth Amendment as a narrow rule against slavery-like forms of involuntary servitude instead of as a capacious mandate for federal protection of equality and freedom. The Peonage Act of 1867 declared that "the holding of any person to service or labor under the system known as peonage is hereby declared to be unlawful, and the same is hereby abolished." ${ }^{103}$ The penalties section of the act called for fines of up to five thousand dollars and five years imprisonment. ${ }^{104}$ When the Court upheld the Act in the Peonage Cases ${ }^{105}$ in the 1910s, it targeted a system of involuntary servitude in which an employee was

99. Jacobus tenBroek, Thirteenth Amendment to the Constitution of the United States: Consummation to Abolition and Key to the Fourteenth Amendment, 39 CAL. L. REV. 171, 190-200 (1951) [hereinafter tenBroek, Consummation to Abolition]. Congress ratified the Fourteenth Amendment in order to ensure the constitutionality of the Act. JACOBUS TENBROEK, EQUAL UNDER LAW 201-33 (1969).

100. 83 U.S. 36 (1872).

101. 109 U.S. 3 (1883).

102. See, e.g., Hodges v. United States, 203 U.S. 1, 17 (1906) (invalidating a statute making it an offense against the United States, subject to federal suit, for private individuals to intimidate or force African American citizens to desist from performing their employment contracts); Civil Rights Cases, 109 U.S. at 25 (holding that Congress has the power only to provide remedies for state action violating section 1 of the Fourteenth Amendment, and that section 5 does not empower Congress to enact laws affecting private rights and defining the "badges and incidents" of servitude prohibited by the Thirteenth Amendment narrowly); Slaughter-House Cases, 83 U.S. at 78-79 (refusing to hold Louisiana's slaughterhouse monopoly a violation of the Thirteenth or Fourteenth Amendments on the ground that they were not intended to displace the central role of the states as protectors of their own citizens).

103. Act of Mar. 2, 1867, ch. 187, § 1, 14 Stat. 546 (codified as amended at 42 U.S.C. $\S 1994$ (1994)).

104. Id.

105. United States v. Reynolds, 235 U.S. 133, 150 (1914) (striking down as unconstitutional a state statute allowing private employers to hire convicts as laborers without fixing any limits on the power of employers over the convicts); Bailey v. Alabama, 219 U.S. 219, 244-45 (1911) (striking down as conflicting with the Thirteenth Amendment an Alabama law that made the refusal or failure to perform contract labor without refunding the money or paying for property received prima facie evidence of criminal conduct). 
forced to work out a debt to an employer. ${ }^{106}$ Although the Court still expressed free labor aspirations, it defined peonage narrowly and reinforced the notion that the Thirteenth Amendment was a rule that abolished a small and diminishing category of unfree servitudes without touching either the core racial or class inequalities of American society. ${ }^{107}$

Despite its narrow scope, by World War II the Peonage Act remained one of the few Reconstruction tools that had been used successfully in the past. In reviewing the statutes under which the Department of Justice had authority to prosecute civil rights violations, the Peonage Act appeared to be a promising wedge with which to broaden federal authority. Thus, what had been a rather small set of harms redressable under the Thirteenth Amendment earlier in the century took on far greater importance during World War II. ${ }^{108}$ Again and again, when Civil Rights Section lawyers discussed their mandate, the right to be free from involuntary servitude played a prominent role. As one Section lawyer noted, "No small part of the work of the Civil Rights Section is that concerned with the enforcement of the right secured by the Thirteenth Amendment, the right of persons to be free of involuntary servitude." ${ }^{, 109}$ Another noted that "the importance of these relatively old laws, designed to eradicate every form of

106. See generally Pete Daniel, The Shadow of Slavery: Peonage in the South, at xi (1972) (describing "the neglected world of peonage" in America from 1901 to 1969); DANIEL NovaK, The Wheel of Servitude: Black Forced Labor AfTer Slavery (1978) (describing the legal mechanisms that reenslaved blacks and the southern economy's dependence on forced labor).

107. See, e.g., Bailey, 219 U.S. at 242 ("The essence of the thing [peonage] is compulsory service in payment of a debt.").

108. For example, three peonage cases reached the Supreme Court during the war, the first to do so since 1914. See Pollock v. Williams, 322 U.S. 4, 25 (1944) (striking down Florida's contract fraud law, which was similar to the laws struck down in Bailey and Taylor); United States v. Gaskin, 320 U.S. 527, 529 (1944) (holding that the arrest of a person with intent to force him into labor in repayment of a debt is a violation of the person's Thirteenth Amendment rights, even if no labor is actually performed); Taylor v. Georgia, 315 U.S. 25, 31 (1942) (finding that Georgia's contract fraud law, which was similar to the law struck down in Bailey, was a violation of the Thirteenth Amendment). The Civil Rights Section prosecuted Gaskin and filed an amicus curiae brief, the first by the Department of Justice in a civil rights case, in Taylor. CARR, supra note 13 , at 148 .

109. Fred G. Folsom, A Slave Trade Law in a Contemporary Setting, 29 CORNELL L.Q. 203, 203 (1943). 
compulsory labor, cannot be overemphasized." ${ }^{110}$ And Rotnem concluded that "[p]robably no single constitutional provision is the basis of so many complaints to the Department" as the Thirteenth Amendment. ${ }^{111}$

\section{B. The Thirteenth Amendment's Unique Advantages: Federal Jurisdiction and State Action}

The question from the current vantage point-at a time when peonage and involuntary servitude are relatively marginalized within civil rights practice and doctrine ${ }^{112}$ - is how the Thirteenth Amendment attained a central place in the Department of Justice's civil rights practice in the 1940s. The answer is rooted in the doctrinal concerns of the Department of Justice, as well as in the particular consciousness of African Americans regarding the Thirteenth Amendment right, as one Section lawyer put it, "to be free from bondage." Aside from the seemingly immovable Equal Protection precedent of Plessy, the two primary doctrinal challenges the lawyers faced as they set out to fulfill Murphy's mandate were federal jurisdiction and the state action requirement. ${ }^{114}$ Because of the post-Reconstruction Supreme Court interpretations of the Reconstruction laws and statutes, very few rights came within the category of those the federal govern-

110. Peonage and Slavery: Hearing on H.R. 2118 Before the House Comm. on the Judiciary (Subcomm. no. 4), 82d Cong. 3, 3 (1951) (statement of George Triedman, Chief, Civil Rights Division, Department of Justice).

111. Rotnem, Criminal Enforcement, supra note 9, at 21.

112. Of course, the Department of Justice still pursues prosecutions under the involuntary servitude statutes. Such cases often involve immigrant labor, agricultural labor, and migrant labor.

113. Brodie, supra note 9, at 390 ("Every form of compulsory service, including serfage and peonage, as well as slavery, clearly was abolished by the [Thirteenth] Amendment.").

114. Section 1 of the Fourteenth Amendment states in part: "No state shall make or enforce any law which shall abridge the privileges or immunities of citizens of the United States; nor shall any State deprive any person of life, liberty, or property, without due process of law; nor deny to any person within its jurisdiction the equal protection of the laws." U.S. CONST. amend. $\mathrm{XIV}, \S 1$. Shortly after its ratification, the Supreme Court defined "the privileges and immunities of citizens of the United States" in a narrow way, so that federal jurisdiction over the states with regard to individual rights was limited. The Slaughter-House Cases, 83 U.S. 36, 74-82 (1872). But see Kevin Christopher Newsom, Setting Incorporationism Straight: A Reinterpretation of the Slaughter-House Cases, 109 YALE L.J. 643, 649 (2000) (arguing that the SlaughterHouse definition of privileges and immunities included all of the Bill of Rights). Moreover, in the Civil Rights Cases, the Supreme Court interpreted the language of the Amendment, and legislation enacted pursuant to section 5, as reaching only governmental, not private, action. 109 U.S. 3, 11-12 (1883). 
ment, as opposed to the states, could protect. Hence, federal jurisdiction seemed to cover only a small subset of rights. Moreover, as a result of post-Reconstruction decisions like the Civil Rights Cases, most rights protected individuals only from the actions of the state and not from private harm.

Recognizing the challenge to federalism they were undertaking, the attorneys of the Civil Rights Section during and after the war constantly referred to and made attempts to overcome the limits on their power. Rooting aggressive federal action in the Reconstruction amendments and statutes, which Biddle saw as "constitut[ing] the sole source of the power of the Federal Government to protect individual rights against encroachment by the States and, in some instances, by individuals," ${ }^{115}$ Biddle chose his test cases carefully so as to control precedent and broaden the scope of the laws. He followed Attorney General Jackson's policy requiring U.S. Attorneys and FBI agents to receive permission from the Civil Rights Section to investigate and prosecute civil rights cases. ${ }^{116}$ Although this requirement no doubt served to restrain some prosecutions by U.S. Attorneys, the Civil Rights Section could coordinate test cases and ensure that only those with a likelihood of success and beneficial precedential value would go forward. ${ }^{117}$

In reviewing the statutes under which the Department of Justice had authority to prosecute civil rights violations, the peonage statute came up repeatedly as one in which federal jurisdiction was certain. While the Department struggled to gain jurisdiction over election

115. Biddle, supra note 33, at 9.

116. O. John Rogge, Supp. No. 1 to Circ. No. 3356 (May 21, 1940), in 16 CIVIL RigHTS, THE White House, AND the Justice Department, 1945-1968, at 12-13 (Michael R. Belknap ed., 1991).

117. See Elliff, supra note 66, at 608-09 (describing how this policy enabled the Department of Justice to control test cases and the FBI to lower its caseload). 
fraud, ${ }^{118}$ lynching, ${ }^{119}$ and police brutality, ${ }^{120}$ it harbored no doubts about peonage. Lynching, though sensational and abhorrent, was an apparently poor candidate for federal prosecutions. ${ }^{121}$ Attorney General Murphy wrote Walter White of the NAACP that the lynching complaints White had forwarded to the Department were "purely local offenses not within the scope of any Federal statute."122 On the other hand, even as the Department attempted to expand the boundaries of what courts would consider involuntary servitude in the later 1940s and early 1950s, the core harm of peonage provoked no jurisdictional uncertainty. Moreover, for members of the Civil Rights Section, the peonage statute was already well known and time tested. ${ }^{123}$ Institutional memory and judicial precedent lent such prosecutions an air of familiarity, and the Civil Rights Section pursued them with alacrity.

118. See Biddle, supra note 33, at 24 ("Sections 51 and 52 of Title 18 were invoked to penalize the miscounting and destruction of the ballots in the primaries."); Rotnem, Clarification, supra note 9, at 255 ("The question presented to the court [in the Classic case] was whether the right of qualified voters in Louisiana to have their votes counted ... was a right 'secured by the Constitution' in the sense that the language is employed in Sections 51 and 52, Title 18, United States Code."). The Department of Justice succeeded in United States v. Classic, 313 U.S. 299, 311 (1941).

119. See Biddle, supra note 33, at 27 ("As most lynchings occur after the arrest of the victim, it should be possible, in spite of United States $v$. Harris, to punish both mob members and delinquent officials whenever there is any form of official connivance or participation."); Coleman, supra note 9, at 425-26 (describing how the Civil Rights Section responded to the 1942 Sikeston lynching and other lynchings of the World War II era).

120. See Biddle, supra note 33, at 28-29 ("The Federal Courts will probably not incline to open their doors wide to review every unlawful act of local officials."). The Department of Justice succeeded in Culp v. United States, 131 F.2d 93, 95 (8th Cir. 1942) (affirming a conviction for conspiring to deprive individuals of federal rights under color of state law). In Screws v. United States, however, the Civil Rights Section faced a setback when the Court held that the defendants did not have specific intent to deprive the victim of his rights; without such intent, no conviction under section 242 could be upheld. 325 U.S. 91, 103-05, 113 (1945). Despite the heightened requirements under Screws, the Department procured a conviction in Crews v. United States, 160 F.2d 746, 747 (5th Cir. 1947) (affirming a conviction for deprivation of federal rights under color of state law).

121. See Harvard Sitkoff, A New Deal for Blacks: The Depression Decade 26897 (1978) (discussing lynching and the Roosevelt administration's handling of it); Dominic J. Capeci, Jr., The Lynching of Cleo Wright: Federal Protection of Constitutional Rights During World War II, 72 J. AM. HIST. 859, 874-78 (1986) (discussing the failed attempts by the Civil Rights Section to bring lynchings within federal jurisdiction); Christopher Waldrep, War of Words: The Controversy over the Definition of Lynching, 1899-1940, 66 J. S. HIST. 75, 79-80 (2000) (discussing various campaigns against lynching and the difficulty of procuring federal action).

122. FINE, supra note 15 , at 90.

123. Schweinhaut, supra note 9 , at 209. 
The attorneys whose task it was to prosecute civil rights violations had to overcome not only a lack of broad federal jurisdiction but also the obstacle of state action. Especially since the lawyers were reluctant to challenge state laws requiring segregation, they needed to find authority for prosecuting civil rights violations perpetrated by private individuals. The Fourteenth and Fifteenth Amendments protected individuals against action by government only, however, so injuries and discriminations perpetrated by private individuals presented tricky problems for prosecution. ${ }^{124}$ Theorizing their way around the state action requirement occupied much of the time of the Civil Rights Section staff. Rotnem and Biddle both tried to find circumstances in which state inaction could be construed as action, such as when the victim was in the custody of the police. ${ }^{125}$ Using the "inaction theory," the conspiracy statute, ${ }^{126}$ and the "color of law statute," the Department attempted to reach as many harms as possible. As the war progressed and the successful cases began to accrue, Rotnem proudly announced that under the civil rights statutes "[p]owers much greater than most people realize reach all the way down to the source of many of our most difficult problems - the behavior of local enforcement officials." ${ }^{, 28}$ These Fourteenth Amendment-based statutes still could not usually reach private individuals, however. In addition to the difficulties of finding federal jurisdiction, the frequent lack of state action rendered rights violations such as lynching largely out of reach of Civil Rights Section prosecutions throughout this period.

The Thirteenth Amendment, on the other hand, did not present the state action problem that plagued the Fourteenth and Fifteenth Amendments, many Reconstruction statutes, and the Bill of Rights. The Thirteenth Amendment declared that "neither slavery nor invol-

124. The Fourteenth Amendment commands, "No state shall make or enforce any law ...." U.S. CONST. amend. XIV, $\S 1$. The Fifteenth Amendment states that, "The right of citizens of the United States to vote shall not be denied or abridged by the United States or by any State." U.S. CONST. amend. XV, § 1.

125. Biddle, supra note 33, at 28 (discussing how the Fourth Circuit in United States v. Catlette, 132 F.2d 902 (4th Cir. 1943), reaffirmed Senator Freylinghuysen's 1871 "inaction theory" of "color of law" by affirming a conviction in the Jehovah's Witness case described below); Rotnem, Clarification, supra note 9, at 260 (discussing a case in which police refused to act after a mob, including the police chief, detained a group of Jehovah's Witnesses, forced them to take castor oil, tied them up, and paraded them through the streets).

126. 18 U.S.C. $\$ 241$ (1994).

127. Id. § 242 .

128. Rotnem, Civil Rights During the War, supra note 9, at 409. 
untary servitude ... shall exist within the United States." "In sharp contrast" to the state action requirement in those amendments, Rotnem wrote, "is the Thirteenth Amendment ... a general prohibition which applies not only against the States and the federal government but also against all individuals who seek to enslave others." ${ }^{130}$ Consequently, as the Department of Justice tried to theorize its way out of the state action problem, the Thirteenth Amendment and its enforcement legislation stood out as promising possibilities for prosecutorial success. As Biddle stated in a 1944 speech,

In short, the application of the criminal sanctions to the protection of civil rights has come to be restricted mainly to cases in which State officials participate, or misuse their power, or situations involving rights granted directly to individuals and guaranteed against individual infringement by the Federal Constitution or laws. For many years, such rights were few in number, limited for the most part to those granted by the Thirteenth Amendment, and to rights under such laws as the Homestead Acts and other Federal land laws. ${ }^{131}$

Because of this unique doctrinal position of the Thirteenth Amendment and its statutes, involuntary servitude remained near the center of the Civil Rights Section's agenda and helped set the parameters of a public civil rights jurisprudence.

\section{Jurisdiction and Rights Consciousness as Feedback Loop}

The relatively straightforward legal issues involved and the successes of the federal government in prosecuting and publicizing peonage cases during the war years raised public awareness about the right to be free from involuntary servitude. As one Civil Rights Section lawyer explained in the early fifties, "the public cannot be expected to be familiar with the extremely technical body of law under the Fourteenth Amendment and the limited boundaries of federal jurisdiction in the field of "due process of law." "On the other hand," he continued, "forced labor as such falls within the federal jurisdiction by virtue of the broad grant of rights in the Thirteenth Amendment." ${ }^{132}$

129. U.S. CONST. amend. XIII, § 1.

130. Rotnem, Criminal Enforcement, supra note 9, at 19.

131. Biddle, supra note 33, at 18.

132. Brodie, supra note 9 , at 374 n.35. 
African Americans saw the federal government as protecting their right to be free from slavery, and their rights consciousness visà-vis the Thirteenth Amendment differed enormously from that regarding Jim Crow and other kinds of racial inequality. Although the Supreme Court had repudiated expansive visions of the Thirteenth Amendment, it had never denied its force altogether. Any effort against segregation had to contend with Plessy v. Ferguson, ${ }^{133}$ however. Because the federal government's position on the most extreme forms of involuntary servitude was not compromised in the way its position on segregation was compromised after Plessy, African Americans backed their claims to be free from involuntary servitude with a seventy-five-year-old entitlement.

Not only did African Americans perceive that they enjoyed such a right, but they also knew that it was federally protected. Thus, one NAACP branch member wrote to an employer alleged to have held an African American in servitude:

It APPEARS that [y]ou took advantage of him due to his skin being black and yours white, which in some instance have been going on in this Country for low these many years. However allow us to call your attention to the fact that this is a strict violation of the Law. That is to subject any HUMAN BEING TO SLAVERY OR PEONAGE and the person or persons that commits or commit such acts charges can be filed against them in Civil or Criminal Federal Court of The U.S. and if found guilty will be fined accordingly. ${ }^{134}$

While a complaint against segregation might have expressed aspirations for an anti-racist law, it was unlikely to have expressed the clear sense of legal entitlement exhibited in this NAACP member's letter. $^{135}$

133. 163 U.S. 537, 540-52 (1896) (holding that separate public accommodations for African Americans are constitutional, so long as the accommodations for each race are equal).

134. Letter from J.C. McMurphy, President, \& Edward Jones, Secretary, Alexandria Branch, NAACP, to Richard McLemoore (Nov. 22, 1947) (reproduced as in original document) (NAACP and Labor, 1940-1955, Part 13 Group II, Box 112).

135. Consider the following complaint:

Most Excellent President ... You, that taken an oath when entering office that You, would up hold the Constitution of the U.S.A. ... I am sure that the thirty one million negroes in the United States want this fully investigated. And I do know that if You, just speak the words and these shackles will fall off these people leggs.

Letter from Booker T. Fossett to Franklin D. Roosevelt, President, United States of America 2 (Mar. 16, 1942) (reproduced as in original document) (on file with the Duke Law Journal). William Henry Huff, an African American lawyer and crusader against peonage, is not representa- 
A feedback loop developed between federal enforcement and rights consciousness. One author found an increase in cognizable peonage complaints due to "increased awareness by the public of the Government's interest and its powers in this area, and the experience acquired by its personnel." ${ }^{136}$ The report of the President's Committee on Civil Rights in 1947, which contained several sections on peonage, also contributed to interest in such cases. ${ }^{137}$ Aware of the Thirteenth Amendment, the federal mandate over involuntary servitude, and the Justice Department's role in enforcing the prohibition, the public generated complaints about it:

$[T]$ here is little doubt that when the Government evinces an interest in a course of conduct or situation, the persons involved will reflect upon their deportment. Those who did not know that what they were doing is legally wrong might very well voluntarily correct their errors. The willful, deliberate wrongdoer might cease his operations through fear of punishment. But it would seem that successful prosecutions and severe sentences, together with effective education, will completely eradicate the continuing peonage, slavery, involuntary servitude evils. ${ }^{138}$

The feedback loop galvanized not only individuals but civil rights organizations as well. William Henry Huff, a black lawyer who crusaded against peonage during the war with the Abolish Peonage Committee, "often reminded the Department of Justice" of Rogge's statement that "there were adequate laws on the statute books with

tive of most African Americans at the time. He does, however, express the same kind of rights consciousness quite well:

Mr. President, I think you know by now that the Negro people of this country are looking to you for a new emancipation so that that new form of slavery known sa peonage, which entered the back door as the Proclamation of immirtal Lincoln drove chattel slavery out of the front door, should be abolished now for all time to come, and we believe you will do it as no other can. There are laws on the statute books sufficient to wipe it away. These laws only need to be vigiously enforced.

Letter from William Henry Huff to Franklin D. Roosevelt, President, United States of America (Nov. 25, 1944) (reproduced as in original document) (on file with the Duke Law Journal).

136. Brodie, supra note 9 , at 373 . Sydney Brodie attributed the fact that "a proportionately greater percentage of involuntary servitude, slavery and peonage complaints are eventually prosecuted in court than are complaints related to the civil rights statutes" to the public's greater understanding of the prohibition against forced labor. Id. at 374.

137. Id. at 373; see also To SECure These Rights: The Report of The President's Committee on Civil Rights 29-30, 107-08, 128, 158 (1947) [hereinafter President's COMMITTEE ON CIVIL RIGHTS] (discussing involuntary servitude laws, cases, and recommendations for statutory changes).

138. Brodie, supra note 9, at 397. 
which to stamp out peonage." ${ }^{139}$ He saw it as his duty to "point[] out those laws to the Department, together with cases that have been successfully prosecuted under and by virtue of those laws." ${ }^{, 140}$ By 1944, Thurgood Marshall of the NAACP was convinced of the sincerity of the Civil Rights Section with regard to peonage complaints. "The Department of Justice is definitely working on peonage cases, and there is no doubt that we will see increased action against this type of lawlessness," he wrote. ${ }^{141}$

The Department took those cases because the law was relatively clear, the public witnessed the Department's successes in such cases, and complainants continued to make their charges known. The opaque nature of federal jurisdiction over other kinds of crimes-to both government attorneys and the American public-meant that such a feedback loop was harder to set in motion for other civil rights violations. The rights consciousness of African Americans, which generated a constant flow of complaints concerning involuntary servitude, combined with the advantages of the Thirteenth Amendment in overcoming the obstacles of federal jurisdiction and state action, meant that the Amendment could easily fill at least part of the newly prominent space for civil rights enforcement at mid-century.

\section{RECONFIGURING THE THIRTEENTH AMENDMENT, REDEFINING INVOLUNTARY SERVITUDE}

In Part III, I showed how the Civil Rights Section lawyers went about finding authority for federal civil rights prosecutions and what led them specifically to the Thirteenth Amendment. This part elucidates how the Department of Justice lawyers improvised within the constitutional and statutory language they found and applied it to new cases and contemporary circumstances. Building on the familiar peonage statute, they began to expand the meaning and scope of the Thirteenth Amendment to reach other impediments to free labor they witnessed around them in the 1940s.

During World War II and the years that followed, the Civil Rights Section's uses of the Thirteenth Amendment reflected a

139. Letter from William Henry Huff to Walter White, Secretary, NAACP 1 (Nov. 24, 1941) (on file with the Duke Law Journal).

140. Id.

141. Letter from Thurgood Marshall to Frank McAllister (Dec. 17, 1941) (NAACP and Labor, 1940-1955, Part 13 Group II, Box 112). 
broadening of the Amendment's meaning from a Lochner-era emphasis on debt to include servitude that resulted from other types of legal, economic, and social coercion. At the beginning of the war, the Thirteenth Amendment was almost synonymous with the turn of the century definition of peonage as coerced labor in payment of a debt created by a contract between two individuals. The three Thirteenth Amendment cases that rose to the Supreme Court during World War II all conformed to this conventional definition of peonage. ${ }^{142}$ But those cases, particularly Pollock v. Williams, also provided support for the Justice Department's broadening efforts.

The Section's first task was to unshackle the conception of involuntary servitude from one limited to private contractual debt. Thereafter, the Civil Rights Section lawyers broadened the meaning of involuntary servitude in two additional ways. First, they included in their definition legal constraints on laborers beyond those imposed directly by employer on employee. Second, they expanded their understanding of involuntary servitude to include not only the availability of exit but also the conditions in which laborers found themselves working. As the war progressed, and after it had ended, the scope of harms under the Thirteenth Amendment expanded to include not only peonage and involuntary servitude but "peonage-like conditions" within the wider world of labor and work.

\section{A. From Peonage to Involuntary Servitude, from Policing Private Contracts to Vindicating Civil Rights}

In the early twentieth century, the Supreme Court interpreted the Peonage Act of 1867 to prohibit only involuntary servitude in which debt was the mechanism of coercion. ${ }^{143}$ Only after a laborer became indebted to an employer and the employer refused exit, retrieved him after exit, or had him arrested, would courts apply the

142. Pollock v. Williams, 322 U.S. 4, 25 (1944) (striking down Florida's contract fraud law, which was similar to the laws struck down in Bailey and Taylor); United States v. Gaskin, 320 U.S. 527, 529 (1944) (holding that the arrest of a person with intent to force him into labor in repayment of a debt is a violation of the person's Thirteenth Amendment rights, even if no labor is actually performed); Taylor v. Georgia, 315 U.S. 25, 31 (1942) (finding that Georgia's contract fraud law, which was similar to the law struck down in Bailey, was a violation of the Thirteenth Amendment).

143. See, e.g., United States v. Reynolds, 235 U.S. 133, 144 (1914) (“"The basal fact [of peonage] is indebtedness ....”') (quoting Clyatt v. United States, 197 U.S. 207, 215 (1905)); Bailey v. Alabama, 219 U.S. 219, 242 (1911) ("The essence of [peonage] is compulsory service in payment of a debt."). 
statute. Outright forced labor cases without the element of debt were arguably more egregious than those that at least painted a veneer of voluntary contract on their surface because they constituted closer approximations of slavery. Such outright forced labor cases had never been successfully prosecuted before World War II, however. ${ }^{144}$ The central relationship of the Lochner-era peonage cases as understood by the courts was a contractual one between employer and employee. The debt element of peonage, and the limitations that hampered executive use of the Thirteenth Amendment other than through the Peonage Act, kept executive enforcement of the Amendment closely tied to its Lochner-era interpretation.

The centrality of contracted indebtedness to the courts in the Lochner-era peonage cases may seem surprising at first glance. The courts of that time had tremendous respect for freedom of contract, and workers who entered into contracts that placed them in debt, which they pledged to work out, were simply exercising their contractual freedom. This, ironically, was Justice Holmes's initial position with regard to peonage. Dissenting in Bailey v. Alabama, he commented that "it certainly would affect the terms of the bargain unfavorably for the laboring man were it understood that the employer could do nothing in case the laborer saw fit to break his word."

As central as contracting was to the jurisprudence of individual rights during the Lochner era, however, respect for the capacity of an individual to contract was not granted to all on an equal basis. Those whom the Court deemed "independent"-like the paradigmatic Lochner bakers-were respected for their capacity to contract, whether they wanted such unlimited rights or not. Thus, the Lochner court wrote,

There is no reasonable ground for interfering with the liberty of person or the right of free contract, by determining the hours of labor, in the occupation of a baker. There is no contention that bakers as a class are not equal in intelligence and capacity to men in other trades or manual occupations, or that they are not able to assert their rights and care for themselves without the protecting arm of

144. See, e.g., Taylor v. United States, 244 F. 321, 325 (4th Cir. 1917) (finding the coercion of a laborer reprehensible but not legally cognizable as peonage because no debt was involved).

145. 219 U.S. at 246 (Holmes, J., dissenting). 
the state, interfering with their independence of judgment and of action. They are in no sense wards of the State. ${ }^{146}$

But like the women of Muller v. Oregon, ${ }^{147}$ those whom the Court deemed "dependent" in some way, or "wards of the state," were not accorded the same deference. Distinguishing the women in Muller from the men in Lochner, the Court found that "history discloses the fact that woman has always been dependent upon man." 148 The Court went on to say:

Though limitations upon personal and contractual rights may be removed by legislation, there is that in her disposition and habits of life which will operate against a full assertion of those rights. ... Differentiated by these matters from the other sex, she is properly placed in a class by herself, and legislation designed for her protection may be sustained, even when like legislation is not necessary for men and could not be sustained. ${ }^{149}$

Their choices, not freely chosen, were due no judicial respect.

The Court not surprisingly viewed the Peonage Cases through this lens of contract. It saw itself as policing the boundaries of private agreements. ${ }^{150}$ Accordingly, the question the Supreme Court asked in the Peonage Cases was whether these particular people, these peons, were capable contractors. They clearly were not. ${ }^{151}$ This meant that their choices, constrained as they were, were not seen by the Court as deserving of deference. ${ }^{152}$ Justice Holmes stated in his concurring

146. Lochner v. New York, 198 U.S. 45, 57 (1905).

147. 208 U.S. 412, 423 (1908) (upholding maximum work hours law for women); $c f$. Adkins v. Children's Hosp., 261 U.S. 525, 533-34 (1923) (finding that the Nineteenth Amendment, conferring suffrage upon women, changed the status of women, and striking down a minimum wage law that applied only to women).

148. Muller, 208 U.S. at 421.

149. Id. at 422 .

150. Benno C. Schmidt, Jr., Principle and Prejudice: The Supreme Court and Race in the Progressive Era, Part 2: The Peonage Cases, 82 ColuM. L. REV. 646, 646 (1982) ("It was in the name of property rights and an imaginative variant on freedom of contract that the Court gave constitutional support to [African Americans].").

151. It is not always clear where African Americans stood in this bifurcated world of independence and dependence. In Hodges, for example, the Supreme Court made clear that African Americans, as a group, were no longer given a special position of protection by the federal government. See Hodges v. United States, 203 U.S. 1, 19-20 (1906).

152. See Fiss, supra note 72, at 176-79 (discussing the importance of contract, and understandings of who could contract, in the early Lochner era). See generally Aviam Soifer, The Paradox of Paternalism and Laissez-Faire Constitutionalism: United States Supreme Court, 1888- 
opinion in Reynolds that "impulsive people with little intelligence or foresight may be expected to lay hold of anything that affords a relief from present pain even though it will cause greater trouble by and by." 153 As a result, legislation preying on such poorly equipped contractors, like the criminal surety legislation in Reynolds ${ }^{154}$ failed under the Thirteenth Amendment.

During World War II, this constitutional understanding of the Court's responsibility to police the private contract no longer held sway. In the Civil Rights Section's practice, the element of contracted indebtedness faded from the center of Thirteenth Amendment enforcement efforts. Attorney General Biddle saw no reason to continue to limit involuntary servitude prosecutions to peonage alone. He accordingly instituted a policy to expand the use of the Thirteenth Amendment beyond the specific, time-worn cases of peonage proper. Early in his tenure, Biddle issued Circular No. 3591, ${ }^{155}$ exhorting his attorneys to pursue cases of involuntary servitude without the element of debt. To underscore the change in approach, Biddle also changed all existing case titles from "Peonage" to "Involuntary Servitude and Slavery." The emphasis of FBI investigations changed accordingly. Prior to the policy change, FBI agents asked peonage complainants detailed questions about the precise amount of debt they owed their employers. Following the change, they focused on the complainants' descriptions of violence and imprisonment-in other

1921, 5 L. \& HIST. REV. 249 (1987) (discussing the paternalistic treatment of peons, sailors, and Native Americans during the Lochner era). The question of why the Court did not also decide cases of involuntary servitude without the debt/contract element is more difficult to answer. One possibility is that such cases did not come their way. The most likely reason for this was the legal strategy of the lawyers bringing these novel kinds of cases. In the wake of judicial restriction of the Reconstruction amendments and most Reconstruction statutes, the untested Peonage Act of 1867 might have appeared more promising than other avenues already limited in their application.

153. United States v. Reynolds, 235 U.S. 133, 150 (1914) (Holmes, J., concurring).

154. Criminal surety laws allowed an individual - usually a landowner or employer-to pay the fine and court costs of another individual—usually a poor, African American laborer. The laborer would then be bound to work off the debt to the employer. Criminal surety provided a private alternative to the chain gang-where the convict would work off his sentence directly for the state. The fact that many arrests were made in order to procure such labor made this system especially pernicious, and led to what Justice Day called in Reynolds "an everturning wheel of servitude." 235 U.S. at 146-47.

155. Reprinted in 16 CIVIL RIGHTS, supra note 116, at 61-63. 
words, the indicia of force and coercion rather than the elements of debt and contract. ${ }^{156}$

The Fifth Circuit's 1944 decision in Pierce v. United States ${ }^{157}$ exemplifies the shift, and how radical the shift seemed at the time. The Pierce majority moved only an incremental step away from the classic case of peonage by finding a violation where the alleged debt was not real but contrived by the employer to keep control over his employees. Removing contract, but not at least the guise of debt, from consideration, the court stated, "In a prosecution for peonage, the law takes no account of the amount of the debt, or the means and method of coercion. It is sufficient to allege and prove that a person is held against his will and made to work to pay a debt." 158 The dissent, however, vociferously protested that in the absence of a contract, a peonage prosecution must fail. To Judge Hutcheson, the evidence showed merely "the fact that [the defendant] claimed [the victims] owed him and, so claiming, subjected them, by threats and putting in fear, to involuntary servitude. ${ }^{159}$ It failed to make out a condition of peonage.

Even in its most incremental implementation, the extent to which the new approach to involuntary servitude represented a break from the past is reflected in the dissent's reliance on long-standing conceptions of peonage. "The statutes have been on the books since 1867 and many cases have been tried under them. No case until this one has ever held that, absent a contract, law or usage requiring service in payment of a debt, a condition of peonage is made out." ${ }^{160}$ He reiterated, "The statute has been on the books for nearly 100 years. Its meaning and effect have become well defined and established. To interpret it now to cover any case of involuntary servitude except one which constitutes peonage is, I think, to do violence to its plain meaning and established construction."161

To interpret the Peonage Act to cover such cases of involuntary servitude without the element of debt was precisely what Biddle intended. Rather than tie the statute to an outdated conception of con-

156. See, e.g., Index compiling "References in Investigative Reports to instances of threats," "the returns of escaped victims," and "to shooting of escaped victims," FBI file on United States Sugar Corporation (circa 1942) (on file with the Duke Law Journal).

157. 146 F.2d 84 (5th Cir. 1944).

158. Id. at 86 .

159. Id. at 88 (Hutcheson, J., dissenting).

160. Id. at 87 (Hutcheson, J., dissenting).

161. Id. at 88 (Hutcheson, J., dissenting). 
tract-based servitude from a century past, Biddle saw it as "a living statute, used to eliminate the various indirect methods by which many persons of low economic status in many of the States will have been forced to labor for a particular employer against their will." ${ }^{162}$ Not only did Biddle reinterpret the Peonage Act, but he also turned to other statutory means of prohibiting involuntary servitude. For the first time since the passage of the Thirteenth Amendment, the Department of Justice used conspiracy and other general civil rights laws to prosecute involuntary servitude even when not based, as peonage was, on an underlying debt. Once the Civil Rights Section lawyers read the Thirteenth Amendment as establishing a "federally-secured right to be free from involuntary servitude," the Reconstruction criminal civil rights statutes-specifically sections 241 and 242-could provide far broader authority for prosecution than the Peonage Act alone. ${ }^{163}$

In addition to moving from an exclusive focus on the Peonage Act to a use of the Thirteenth Amendment in conjunction with the criminal civil rights laws, Civil Rights Section lawyers also began to mine other unused statutes for their potential application to contemporary forms of involuntary servitude. In 1943, Fred Folsom, a Section attorney, suggested the use of a "little known statute best described as the 'Slave Kidnapping' Statute. ${ }^{164}$ He favored the statute, ${ }^{165}$ which prohibited, among other things, the holding of a person as a slave, because of "certain gaps in the applicability of the Civil Rights Statutes and the Peonage Statute. ${ }^{166}$ In particular, he was concerned with those cases in which debt had not been the mechanism of force. ${ }^{167}$ In attempting to "modernize" the slave kidnapping statute for the 1940s, Folsom argued that the word "slave" was not limited to Afri-

162. Biddle, supra note 33, at 8-9.

163. The use of the Thirteenth Amendment in conjunction with the criminal civil rights laws still proved inadequate in combating the harms included in the still broader definition of involuntary servitude that the government embraced as the 1940s progressed. I discuss the additional statutory authority the Department of Justice sought, and used, infra at notes 211-28 and accompanying text.

164. Folsom, supra note 109, at 203. The statute had been used successfully in the Peacher case. See id. at 208 (discussing United States v. Peacher (E.D. Ark. 1937) (unreported)); infra note 172 and accompanying text.

165. 18 U.S.C. $\S \S 423,446$ (1940) (originally enacted as Act of Mar. 4, 1909, ch. 321, §§ 248, 271,35 Stat. 1139, 1142) (current version at 18 U.S.C. $\$ 1584$ (1994)).

166. Folsom, supra note 109, at 203.

167. Id. at 203-04. 
can Americans held in the chattel slavery of the antebellum South. Rather, he argued, "'slave' [should] be construed to mean a person so far subjected to the will of another that he is held to labor or service against his will." 168 Rather than confine the term to the distant and unusable past, he "prefer[red] to consider the act as framed for post bellum conditions, in the light of the war amendments, and as using the word slave as meaning a person in a state of enforced or extorted servitude to another." ${ }^{\text {169 }}$ Folsom was more concerned about eliminating conditions of "virtual slavery" than with proving out the elements of contracted indebtedness. ${ }^{170}$

This reduced concern for contract in involuntary servitude reflects the generally declining importance of contract in Supreme Court jurisprudence after 1937, and points toward an understanding of civil rights that we can recognize today. ${ }^{171}$ The move from "peonage" to "servitude" suggested a regulation of status in contrast to a policing of contracts. The occasional interference of government into private contracts-the essence of Lochner-era peonage cases-gave way to a direct, ongoing relationship between the federal government and its citizens, whereby the government was required to vindicate the citizen's rights when violated by private parties. A jurisprudence based on a model of private contracting ceded to one that emphasized public law and civil rights. In prosecuting involuntary servitude, the federal government extended further the protections the New Deal had provided American citizens in the form of Social Security, unemployment insurance, and other economic and welfare programs. Government as umpire gave way to government as protector, and private law gave way to civil rights.

\section{B. Broadening Involuntary Servitude I: Attacking Legal Obstacles}

Prior to the 1940s, in addition to proving the element of debt, prosecutors also had to prove physical or legal coercion to labor-coercion applied directly and explicitly by the employer to the em-

168. Id. at 206.

169. Id. at 209.

170. Id. at 214 .

171. Ten years later, Brodie noted this shift from peonage to involuntary servitude, emphasizing that "the unconcern with the debt element of the slavery and servitude statutes should suggest [the involuntary servitude statutes'] more extensive use in appropriate situations." Brodie, supra note 9 , at 384 . 
ployee. A laborer had to show that attempts to leave the employment would be met with physical force, arrest, or imprisonment in order to make out a peonage claim. The most celebrated incidents of peonage were those in which the force was most brutal and obvious. In the Peacher $^{172}$ case in Arkansas in 1937, for example, Peacher had kept his workers in something resembling a "chicken house" with bars over the windows, armed guards, and dogs. ${ }^{173}$ Even into the 1940s, this focus on physical and legal restraint continued. Thus, in 1941, William T. Cunningham actually hunted his fugitive workers all the way from Oglethorpe County, Georgia, to Chicago, where he convinced the police to arrest them. ${ }^{174}$ And a large-scale investigation into Florida's United States Sugar Corporation revealed numerous instances of violence and threats of violence. ${ }^{175}$

Even as such conventional indicia of immobility remained important to the lawyers in the wartime Civil Rights Section, they began to explore the effects of other obstacles to free labor. Attorney General Biddle himself began the process of looking beyond the individual employment relationship to the structural, legal obstacles to laborer mobility in the South. Recognizing that employer coercion was not the only impediment to the free labor the Thirteenth Amendment promised, Biddle moved the focus from individual laborers to the southern labor market itself.

Biddle was aided in this goal by the Supreme Court's opinion in the 1944 peonage case of Pollock v. Williams. ${ }^{176}$ In Pollock, the Supreme Court struck down Florida's contract labor statute, which made it a crime for a laborer to leave a job without repaying an advance from his employer. ${ }^{177}$ In Pollock's case, his five dollar advance remained unpaid when he left the job. ${ }^{178}$ Although Pollock still contained the element of contracted indebtedness, the expansive language of the Court indicated a broader view of involuntary servitude. Justice Jackson wrote, "The undoubted aim of the Thirteenth Amendment as implemented by the Antipeonage Act was not merely

\footnotetext{
172. United States v. Peacher (E.D. Ark. 1937) (unreported).

173. DANIEL, supra note 106, at 172.

174. Id. at 175.

175. See FBI File on United States Sugar Corporation, supra note 156 (noting numerous reports of beatings).

176. 322 U.S. 4 (1944)

177. Id. at 25 .

178. Id. at 6 .
} 
to end slavery but to maintain a system of completely free and voluntary labor throughout the United States.... [I]n general the defense against oppressive hours, pay, working conditions, or treatment is the right to change employers." ${ }^{, 179}$ Biddle interpreted Justice Jackson's opinion as placing

the right to freedom from involuntary servitude on so broad a base that the way has been opened to an attack on the "enticing labor" and "emigrant agent" statutes, and some of the vagrancy statutes and "work-or-fight" orders which experience has proved to be in reality indirect means of enforcing involuntary servitude, especially against Negro farm hands and laborers. ${ }^{180}$

Biddle thus indicated that prohibiting involuntary servitude meant far more than eliminating the direct coercion of a particular employer upon a particular employee. It meant the creation and protection of a unitary, national labor market. The "enticing labor" statutes to which Biddle referred, for example, imposed penalties on potential employers who hired laborers away from their current employers, making potential employers wary of labor market competition for fear of legal sanctions. These laws thus minimized laborer mobility among employers. ${ }^{181}$ "Emigrant agent" statutes required

179. Id. at 17-18.

180. Biddle, supra note 33, at 25.

181. For arguments that law and/or custom succeeded in curtailing almost all African American movement, see Gerald David Jaynes, Branches Without RoOts: Genesis of THE BLACK WORKING ClASS IN THE AMERICAN SOUTH, 1862-1882, at 307-08 (1986) (maintaining that contract law prevented African Americans' benefiting from competitive markets); Jay Mandle, Not Slave, Not Free: The African American Economic Experience SINCE THE CIVIL WAR 21 (1992) ("[C]onfinement more than opportunity characterized the labor market."); NOVAK, supra note 106, at 1 (discussing the drive to replace slavery with a similar master-slave relationship); Pete Daniel, The Metamorphosis of Slavery, 1865-1900, 66 J. AM. HIST. 88, 96 (1979) (describing the use of various laws to restrict the movement of African American labor); Jonathan M. Wiener, Class Structure and Economic Development in the American South, 1865-1955, 84 AM. HIST. REV. 970, 975 (1979) (noting the use of law and Klan terrorism to prevent migration of African Amercian labor). For those that find that despite the law, African Americans moved relatively freely throughout the South, see RoBERT HIGgS, COMPETITION AND COERCION: BLACKS IN THE AMERICAN ECONOMY, 1865-1914, at 27 (1980) ("[M]any young blacks... did leave the South...."); DANIEL M. JOHNSON \& REX R. Campbell, Black Migration in America: A Social Demographic History 64 (1981) (describing the relocation of African Americans after the Civil War and their migration to mines, mills, and cities in the 1880s and 1890s). For sources that combine both views, see William Cohen, At Freedom's Edge: Black Mobility and the Southern White QUEST FOR RACIAL CONTROL, 1861-1915, at 3 (1991) ("[T]he fifty years after the Civil War were marked by a continuing struggle over how much freedom of movement blacks should 
agents, whose job it was to convince African Americans from the rural South to migrate to the urban North, to pay exorbitant fees in order to operate in each of the counties of the South. ${ }^{182}$ These laws often made employment recruitment impracticable in the South, and closed off the channels of information necessary to facilitate widespread migration for work. ${ }^{183}$

Even if African Americans managed to procure information about jobs with other employers in other locations, vagrancy and hitchhiking laws placed obstacles in the way of exit and mobility. Such laws made simple physical movement from place to place and job to job difficult for many African Americans in the South. Moreover, these state laws and local ordinances were often enforced in a discriminatory fashion. ${ }^{184}$ They served as mechanisms for procuring labor from those African Americans who did not want to labor, and even from those who were already employed. The use of "work-or-fight" laws during World War II provides a striking example of such practices. The sheriff of Broward County, Florida, for example, told an FBI agent that farmers had been

having an extremely hard time during the past winter season getting negro labor to harvest their crops. he again said that there were plenty of negro workers in the area, but that they were independent and refused to work more than a few days each weel. he pointed outthat thousands of dollars of winter vegetables were lost last season for lack of farm hands to pick them. He repeated that his policy of directing negroes to work or go to jail for vagrancy arose out of the above condition and reaffirmed that he felt it his patriotic duty

have."); Roger Ransom \& Richard Sutch, One Kind of FreEdom: The ECONOMiC CONSEQUENCES OF EMANCIPATION 193, 195 (1977) (denying that "labor [was] free to move to its most remunerative employment" but stating that there was a "small but growing migration" of blacks from the postbellum South which "reached impressive proportions" after 1910).

182. See NovAK, supra note 106, at 39 (describing enticement laws); Jennifer Roback, Southern Labor Law in the Jim Crow Era: Exploitative or Competitive?, 51 U. CHI. L. REV. 1161,1169 (1984) (noting licensing fees of up to $\$ 5000$ for each county in which recruiting took place).

183. See Roback, supra note 182, at 1169 ("The primary economic effect of the emigrant agent laws was to increase the cost to black laborers of obtaining information about job opportunities outside their local market area.").

184. In Broward County, Florida, for example, 162 arrests were made for vagrancy between June 1943 and August 1944. Only seven of them were of whites. FBI Report, Edwin B. Poorman, at 3 (Sept. 9, 1944) (National Archives and Records Administration, Record Group 60, Department of Justice: 50-1-14). 
in war-time to require that negroes work on the ground that our men fighting overseas were given no days off. ${ }^{185}$

Although the Section pressed for an indictment in the case and presented it to a grand jury, the jury returned a no-bill. ${ }^{186}$

Biddle's desire for a Thirteenth Amendment prohibition on state and local laws that served to support involuntary servitude in the South both expanded upon and represented a break with the Supreme Court peonage cases of the 1910s and 1940s. Several of those cases invalidated state laws that supported peonage. Those lawscontract fraud and criminal surety in particular-were targeted because they created legal mechanisms of enforcing debt, the "basal fact" of peonage. ${ }^{187}$ The enticement, emigrant agent, vagrancy, hitchhiking, and work-or-fight laws supported general conditions of involuntary servitude, rather than direct peonage. They did not necessarily create an employment relationship from which exit was

185. Id. at 1 (reproduced as in original document). Many organizations publicized the way in which work-or-fight laws facilitated white employers' exploitation of black workers. See, e.g., Maryland "Peonage" Studied, HeRALD TRIBUNE, Sept. 27, 1943, at 21 (reporting a Department of Justice investigation spurred by the Workers' Defense League); see also Forced Labor, 50 CRISIS 105, 105 (1943) (opposing the Austin-Wadsworth Draft Labor Act).

It was said of work-or-fight laws that:

It takes little imagination for colored people to understand what such a bill will do to them. It will place in the hands of administrators the right to freeze Negroes in certain types of work, to remove them from some localities and jobs and force them to new places and new work. There will be virtually no chance to escape from low-paid occupations to better paid jobs... [They will be] at the mercy of the people who now exploit them, and who are angry at the whole war program for "luring" them away from the starvation wages and miserable working conditions of the area.

Forced Labor Again, 50 CRISIs 263, 263 (1943).

Although President Roosevelt (unsuccessfully) favored federal "work-or-fight" laws that used the draft to compel employment and punish strikers, Biddle's image of free labor would not have sanctioned such legislation. See Bartholemew H. Sparrow, From the OUTSIDE IN: WORLD WAR II AND THE AMERICAN STATE 262 (1996) (describing the veto message in which President Roosevelt proposed amending the Selective Service Act to allow for the induction of striking workers into non-combat military service).

186. FBI Report, Edwin B. Poorman (Feb. 6, 1945) (National Archives and Records Administration, Record Group 60, Department of Justice: 50-1-14); see also National Archives and Records Administration, Record Group 60, Department of Justice: 50-3-3 (1943) (containing internal Department of Justice memoranda describing various work-or-fight programs and the Section's handling of them).

187. Bailey v. Alabama, 219 U.S. 219, 242 (citing Clyatt v. United States, 197 U.S. 207 (1905)). In contract fraud, a laborer who took an advance from an employer and left the employment before repaying the advance was presumed to have defrauded the employer. $\mathrm{He}$ could, accordingly, be convicted and imprisoned for the fraud. Id. at 232-39. For a description of criminal surety, see supra note 154 . 
an employment relationship from which exit was difficult; rather, they made exit difficult from any employment relationship.

Biddle hoped to build upon both Pollock's precedent and its rhetoric. He could use the fact that the Supreme Court had invalidated a statute supporting involuntary servitude and the expansive free labor language it used in doing so as weapons with which to attack particularized instances of laborer immobility and also to foster labor mobility more generally. ${ }^{188}$ Pollock's invalidation of the contract fraud law could be applied to a host of other laws. And its expansive language could justify the protection of a robust labor market among both various employers (hence the prohibition against enticing labor statutes) and geographical areas (hence the prohibition against emigrant agent statutes). Biddle thus moved toward a position in which the prohibition of involuntary servitude could include not only direct physical and legal coercion by the employer, but also the larger legal framework that structured southern, especially agricultural, employment.

\section{Broadening Involuntary Servitude II: Focusing on Social and Economic Conditions}

Beginning in the early 1940s and gaining momentum later in the decade and in the early 1950s, the Department of Justice began to treat not only the legal structures that facilitated involuntary servitude, but also the social and economic ones, as potentially coming within the scope of the Thirteenth Amendment. In large part, this further expansion of the meaning of involuntary servitude originated in popular conceptions of "peonage," "slavery," and "servitude." The early 1940s shift from peonage to involuntary servitude made considerable sense to the lay public. Involuntary servitude without debt was closer to slavery, which seemed a more egregious crime in the popular imagination than being forced to work off a debt. Moreover, the rele-

188. On the various statutes restricting labor mobility, and the extent of their success, see StePhen DeCAnio, Agriculture in the Postbellum South: The Economics of PRODUCTION AND SUPPLY 69-75 (1974) (citing anecdotal evidence of both great mobility and restriction); HiGGS, supra note 181, at 75 (claiming that laws restricting mobility were less effective than threats of force or criminal proceedings at restricting movement between employers); William Cohen, Negro Involuntary Servitude in the South, 1865-1940: A Preliminary Analysis, 42 J. S. Hist. 31, 33 (1976) (attempting to explain the paradox of large-scale African American migration under a system designed to restrict such movement). See generally Roback, supra note 182 (exploring economic effects of Jim Crow labor laws). 
vant actors-Congress, the NAACP, social scientists, and African American complainants-increasingly began to emphasize the social and economic conditions of work in understandings of involuntary servitude.

The "realities" of involuntary servitude, which the turn-of-thecentury Supreme Court had been unwilling to acknowledge in its attention to contract, began to constitute its meaning and popular usage in the 1940s. Political scientist Howard Devon Hamilton defined peonage "[i]n every day parlance" as "used loosely to cover almost any variety of forced labor, or simply exploited labor." 189 Coercion was so widespread that "it may well be that there are twenty thousand families who are being subjected to economic and social pressures incompatible with the principle of free labor." ${ }^{, 190}$ Moreover, Hamilton extended his discussion of the Thirteenth Amendment from peonage proper to "peonage-like conditions,"

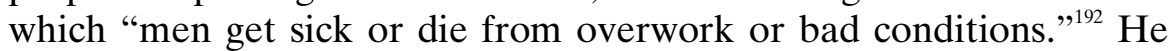
discussed how contract workers were "farm[ed] out" to other employers during slack periods ${ }^{193}$ and how Mexican workers endured "hideous living conditions and ... low wages." ${ }^{\text {"Th }}$ To Hamilton, peonage had come to encompass all of these coercions and indignities within its meaning.

Press releases by organizations like the NAACP began to speak of "virtual slavery," of workers being held "without legal cause and forc[ed] ... to work for the benefit of others." 195 A local NAACP branch requested FBI involvement in a case in which teenage boys from Brooklyn had been lured to a farm in upstate New York. When the boys "complained and asked to be taken home," they were "told if they wanted to leave they'd have to walk." ${ }^{, 196}$ Neither the reporter who wrote about the case nor the NAACP saw the permission to

189. Hamilton, supra note 36 , at 15 .

190. Id. at 72 .

191. Id. at 57.

192. Id. at $57-58$.

193. Id. at 69 .

194. Id.

195. Peonage, selections from A Monthly Summary of Events and Trends in Race Relations, NAACP Papers (Aug.-Oct. 1946) (on file with the Duke Law Journal).

196. Allan Keller, 22 Shanghaied B'klyn Boys Flee Upstate Slave Farm, N.Y. WORLD Telegram \& Sun, Aug. 6, 1953, at 1. 
leave as fatal to the youths' claims of peonage. ${ }^{197}$ Rather, they emphasized that the city youths had "worked like peons ... for little or no money" ${ }^{198}$ in "conditions of practical peonage."199 The conditions of the work, the hardship it entailed, and the inadequate pay sufficed to demonstrate "practical peonage" in the public understanding.

Similarly, the common practice among farmers and employers of selling the debt of their employees to one another, which had long escaped legal notice, began to appear to be beyond the bounds of the legitimate employment relationship. During Senate hearings on the lumber industry in Laurens County, Georgia, testimony revealed new national attention to a very old, long-tolerated practice. Thomas $\mathrm{W}$. Johnson, an attorney from Macon, Georgia, testified, "They actually buy the debts from each other. If one Negro wants to go and work for somebody else and it is satisfactory with the man for whom he is working at the moment, the man with whom he wants to work buys the debt from the other man." ${ }^{200}$ Although the sale of debt arguably may have enhanced worker mobility, the existence of the ongoing debt, and the need for permission of its sale before mobility could be achieved, offended the sensibilities of those interested in ending involuntary servitude. The fact that debts were sold, that people could remain in debt for long periods of time, and that movement between jobs and employers was difficult, albeit perhaps not impossible, were considered indications of a failure of free labor.

The nature of the complaints to the Department of Justice and to organizations like the NAACP reflected these changes in the popular understanding of civil rights. Male agricultural laborers began to complain about the amenities without which they had been forced to

197. The national office of the NAACP, however, informed its branches that immobility was essential to the Department of Justice even looking at a claim:

In order to get the Department of Justice to investigate and take action, it is not sufficient that the Negroes are extremely poor, ignorant of their rights and do not protect themselves by moving and refusing to work. It must be shown that the persons for whom they work actually take steps to prevent them from leaving and to keep them from getting aid in leaving.

Letter from Marian Wynn Perry, Assistant Special Counsel, NAACP, to Edward Knott, Jr., Secretary, Meridian Branch, NAACP (Dec. 1, 1947) (on file with the Duke Law Journal).

198. Keller, supra note 196, at 1.

199. Press Release, NAACP, FBI Asked to Probe New York State Farm (Aug. 6, 1953) (on file with the Duke Law Journal).

200. Labor Practices in Laurens County, Ga.: Hearing Before the Special Subcomm. on Labor and Labor-Management Relations of the Senate Comm. on Labor and Public Welfare, 82d Cong. 87-88 (1951) (statement of Thomas W. Johnson, attorney from Macon, Ga.). 
live, rather than the violent means by which they were forced to work. ${ }^{201}$ After the war, stories of escaping from slavery even began to gain currency among some drifters as a means of support and livelihood. Young men traveled the country, capitalizing on outrage about slavery, pouring out their fictional stories to NAACP branches, black churches, and other organizations. They were welcomed with open arms, positive publicity, places to stay, jobs, and some money. The story of the escaped slave was shocking but believable to this audience. $^{202}$

One young man appears in the NAACP's documents several times as having visited several different cities between 1947 and 1950. The way in which his story changed reveals much about the way peonage was perceived by the public during those years. When he first surfaced at the NAACP office in Atlantic City, New Jersey, his story sounded much like wartime cases of peonage: referred by the United States Employment Service to a farm where armed guards kept hundreds of young men in a barracks, Waver Clifton found himself working for no pay. ${ }^{203}$ After his story was found to be false and he was alleged to be a double murderer, Clifton disappeared. In 1950, he appeared at another NAACP office in Beaumont, Texas. His story had changed to fit the times. Describing how he had been held on a farm as a slave, his allegations mostly concerned the amenities without which he had been forced to live, rather than the violent means by which he was forced to work. "There are no doctors, schools or churches on the farm from which I escaped," he testified in his affidavit. ${ }^{204}$ "I was paid no salary. I was given simple food and clothing and nothing more.... I have never been to school, cannot read or write

201. See, e.g., Letter from Clay A. Williams, Assistant Secretary, Baton Rouge Branch, NAACP, to Thurgood Marshall, General Counsel, NAACP (Feb. 18, 1946) (describing youth who were wearing "rags," and sleeping in a "chicken house" or on an "old rusty cot") (on file with the Duke Law Journal).

202. See, e.g., Memorandum from Franklin H. Williams, to Executive Staff, NAACP (Oct. 22,1947 ) (discussing the Atlantic City NAACP's advancing Waver Clifton money for clothes and other necessities and giving him a job) (on file with the Duke Law Journal); cf. Elizabeth B. Clark, "The Sacred Rights of the Weak": Pain, Sympathy, and the Culture of Individual Rights in Antebellum America, 82 J. AM. HIST. 463 (1995) (discussing antebellum narratives about suffering slaves and how they led to popular acceptance of a human right to be free from physical coercion and pain).

203. Affidavit of Waver Clifton, Atlantic County, N.J. (Aug. 1947) (on file with the Duke Law Journal).

204. Affidavit of Waver Clifton, Jefferson County, Tex. (July 24, 1950) (on file with the Duke Law Journal). 
nor can I count American money or tell time by a clock or watch. We had no contact with the outside world." ${ }^{205}$ Brutality no longer seemed necessary to garner attention, support, and shock value. Rather, a lack of the amenities of modern American life, physical isolation, and deprivation sufficed to do the job.

Moreover, male agricultural workers were joined by others complaining of the poor conditions of their working lives. Whereas cases involving male, southern agricultural laborers held through debt and violence had once predominated, those concerning young women held as domestic servants became far more frequent than in the past. The women emphasized lack of pay, degrading conditions, and hard work. Elizabeth Coker complained that she "never ate a meal at the table the whole time" she worked for the alleged perpetrators and that she slept in the basement and a chicken roost. ${ }^{206}$ At the end of thirteen years of service to her employers, she "had no clothes, no shoes, and but seventy cents in money." ${ }^{207}$ Polly Johnson also complained that she slept in a hen house and suffered sexual abuse, beatings, no wages, poor conditions and treatment, and work too strenuous for a young woman. ${ }^{208}$ She was "not allow[ed]... to have any playmates... was never sent to school nor allowed to visit anyone, nor to attend church." ${ }^{209}$ These complaints are representative in rarely mentioning forced immobility. In fact, Polly Johnson testified not that she was kept by force, but rather that "she was not allowed to leave the premises except when [her employer] sent her to the store and then she had to return within a given period." ${ }^{210}$ Because she could leave the premises unaccompanied, the essence of her servitude was not in the force by which she was held, but rather the conditions that ensured that she would indeed "return within a given period."

205. Id.

206. Affidavit of Elizabeth Coker, El Paso, Tex. (Jan. 30, 1947) (NAACP and Labor, 19401955, Part 13 Group II, Box 112).

207. Letter from LeRoy White, Executive Secretary, El Paso Branch, NAACP, to Thurgood Marshall, General Counsel, NAACP 2 (Oct. 14, 1947) (on file with the Duke Law Journal).

208. Affidavit of Polly Johnson, Washington, D.C. 1-3 (1946) (on file with the Duke Law Journal); see also Letter from Clay Williams to Thurgood Marshall, supra note 201 (describing sleeping in chicken house and clothing like rags). See generally Akhil Reed Amar \& Daniel Widawsky, Child Abuse as Slavery: A Thirteenth Amendment Response to DeShaney, 105 HARV. L. REV. 1359 (1992) (discussing cruel treatment as an element of slavery distinct from labor).

209. Affidavit of Polly Johnson, supra note 208, at 1.

210. Id. 
Metaphorical meanings and nonlegal understandings of words like slavery, peonage, and involuntary servitude converged with the Justice Department's aspirations for the Thirteenth Amendment. As the nature of complaints to the Department began to focus less and less on debt and more and more on the conditions of work, the Department attempted to interpret the law to address the complaints.

In 1948, the recodification of the criminal code slightly modernized the involuntary servitude laws and facilitated their use, but they remained ill-suited for application to many of the complaints that the Civil Rights Section received. ${ }^{211}$ As a result, in 1951, Section Chief George Triedman sought further changes from Congress to the involuntary servitude statutes. Complaints of forced labor conditions kept "coming up and hitting us constantly," he reported, but he and his attorneys found themselves "powerless to go forward" with prosecutions under the laws as they then stood, and "frustrated with a situation where a condition exists like this." ${ }^{212}$ Although the Section had few attorneys and no need for more work as a general proposition, it nonetheless pursued wider jurisdiction in involuntary servitude cases. An omnibus civil rights bill that included "modernization" of the involuntary servitude statutes was pending in $1951,{ }^{213}$ but Triedman sought additional legislation specifically remedying defects in those laws. For example, during the hearings on H.R. 2118, ${ }^{214}$ Triedman tes-

211. As part of the recodification, the peonage and involuntary servitude laws underwent some significant changes. As the revisers described their project, the overall goal was to modernize the federal criminal laws. The title of the chapter including the involuntary servitude laws was changed from the backward-looking "Slave Trade and Peonage" to the more contemporary "Peonage and Involuntary Servitude." Henry Putzel, Jr., a Civil Rights Section attorney, later described how "[u]nder the new provision, [section] 1584, holding a person to a condition of involuntary servitude is made a crime apart from the existence of any debt." Putzel, supra note 8 , at 445 . As a result, the new section allowed prosecutors to avoid the slightly clumsy combination of the Thirteenth Amendment and the criminal civil rights laws. Both the 1948 revisers and Putzel, however, recognized that further expansion was necessary. Putzel acknowledged that "further clarifications [were] still in order." Id. The revisers specifically noted that the peonage and involuntary servitude chapter was one that required significant changes in the near future.

212. Hearing on Peonage and Slavery Before Subcomm. No. 4 of the House Comm. on the Judiciary, 82d Cong., 1st Sess. (1951) (Statement of George Triedman, Chief, Civil Rights Section, Criminal Division, Department of Justice) (unpublished hearing, on file with the Duke Law Journal) [hereinafter Hearing on Peonage].

213. Id. at 29 (discussing the amendments to $\S 1583$ suggested in H.R. 29, 82d Cong. (1st. Sess. 1951)).

214. H.R. 2118, 82d Cong. (1st Sess. 1951), reprinted in Hearing on Peonage, supra note 212, at $1-2$. 
tified that the bill would cover attempts to place individuals in involuntary servitude:

There has been a fairly complete investigation to determine if there are any laws to accomplish this and we have found there are not.... [T]here are actual cases of happenings that have come across my table as well as members of my section and there are no other laws to meet them. That is what prompted us, even at this late date, even after 75 years, to come in and see if we can modernize them a bit. ${ }^{215}$

During these hearings, the kinds of cases Triedman described illustrate how much the Section's view of involuntary servitude had changed between the beginning of World War II and 1951. The classic case of peonage - of the poor black man in the rural South, held for debt in either agricultural or rural nonagricultural work (like timber or sugar refining) by force of arms, violence, and threats of violence and arrest-had given way to a far broader understanding about who was forced to work and how. For example, Triedman discussed cases concerning female domestic workers, in contrast to almost all of the cases from the war and earlier. He described one case in which a female domestic worker had left her employment, but her employers had forbidden her son to leave with her. The Department hoped to prosecute the employer for holding the son (who was not employed by the perpetrators) and for holding the mother (who was no longer in their custody because they had allowed her to leave). ${ }^{216}$ Two types of coercion were at issue in the case: attempting to retain an employee by refusing to allow something or someone she cared about to leave the premises, and holding someone with no intention of forcing him to work. The kind of coercion at work in peonage as defined by the Supreme Court in the 1910s played no part in such a case. Although Triedman tried to assure hostile southern congressmen that "the Bill would effect no radical change in existing law and would not extend the jurisdiction of the Department to any new situation or type of case," ${ }^{217}$ his domestic worker examples belied those reassurances. Such examples were revolutionary, as they indicated a willingness to use the federal law to intrude into relationships of household labor.

215. Hearing on Peonage, supra note 212, at 13-14.

216. See id. at 14-15 (noting that an investigation was being conducted to determine if the son was being held in involuntary servitude).

217. Id. at 28 . 
Such forms of coercion had never before received more than cursory investigations from the Department. In the past, the federal government had left such situations to state laws against kidnapping, and the members of Congress that comprised Triedman's audience were content to leave jurisdiction over such cases to the states. ${ }^{218}$ Already by the late 1940s, however, conditions cases figured prominently among the types of cases the Civil Rights Section was determined to reach using the Thirteenth Amendment and involuntary servitude statutes. For example, the Department brought charges to a grand jury against Elizabeth Coker's employers, who had held the young woman, without pay, and forced her to perform strenuous work in terrible conditions. ${ }^{219}$ Triedman's intention to prosecute such cases federally under the Thirteenth Amendment could have expanded dramatically the kinds of harms federal civil rights law could reach.

Despite the difficulties Triedman and his lawyers faced in applying the extant laws to cases for which they arguably had not been intended, the Section did enjoy some successes. ${ }^{220}$ A case similar to Elizabeth Coker's reached trial in 1947, and in its opinion finding the defendants guilty of holding Dora Jones to slavery, the trial court emphasized the conditions of Jones's life in a way never before discussed in a published opinion: ${ }^{221}$

There is an abundance of evidence which establishes that for many years prior to the date charged in the indictment, defendant Elizabeth Ingalls kept one Dora L. Jones, a negro woman, in her household as a servant during a period in excess of twenty-five years. There is evidence that during an uninterrupted period of in excess of twenty-five years said servant was required to arise at an early hour in the morning and perform practically all of the household labor in connection with the maintenance of the Ingalls household. She was forbidden to leave the household except for the commission of errands and performed drudgery of the most menial and laborious type, without compensation. She had no days off from her work, no

218. See id. at 12, 15, 17-19 (questions of Congressmen Forrester, Jones, and Hillings) (suggesting that state kidnapping laws could cover such offenses).

219. Letter from LeRoy White to Thurgood Marshall, supra note 207, at 1-2. Due largely to racial discrimination in the convening of the jury, no indictment followed. Id.; see also supra notes $185-86$ and accompanying text.

220. Folsom stated that, in 1943 , he expected two trials on the basis of section 443 , and that of the 24 or 25 investigations under way, "another handful of indictments charging this crime will probably be forthcoming." Folsom, supra note 109, at 204.

221. United States v. Ingalls, 73 F. Supp. 76, 77 (S.D. Cal. 1947). 
vacation. Her quarters were among the poorest in the several homes occupied by the defendant during this period of years. There is evidence that the food furnished to her by defendant was of a substantially lower standard than that common to servants generally. She was denied the right to have friends and was required to send away a relative who called upon her. ${ }^{222}$

The kinds of threats that the court concluded prevented Jones from exercising her "free will" 223 were also different in kind from earlier indicia of forced immobility. Although Ingalls threatened Jones with imprisonment, it was for an adulterous affair that had occurred thirty-eight years prior and for an also distant abortion. Ingalls also told Jones that "she was not bright, mentally, and could not make her way in the competitive world and would-if not sent to prison-be committed to a mental institution." 224 Although the threats were less than credible, and the warnings went more to undermining Jones's confidence in her ability to leave than to prohibiting her from doing so, the court took seriously Jones's subjective perception of her options, rather than any objective harm that would come to her. "It appears that these threats and numerous others acted effectively upon the servant to hold her against her free will in the service of the defendant.",225

Perhaps more important, the case was prosecuted under section 443 of the criminal code, the section Folsom had recommended using in 1943, which prohibited holding a person to a condition of slavery. The conditions of Jones's life were thus central to the court's description of the harm. The court spent considerable energy canvassing the many definitions of slavery, and the many ways in which it need not conform to the chattel slavery that existed prior to the Civil War. The essence of slavery, for the court, was the subjection of the will of one individual to that of another. ${ }^{226}$ After detailing additional poor treatment, the court concluded,

These facts, gleaned from a great mass of other evidence of similar treatment, compel the conclusion that the servant, Dora L. Jones,

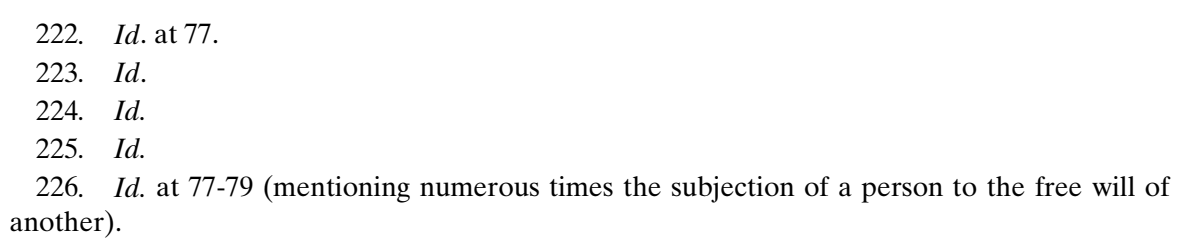


was a person wholly subject to the will of defendant; that she was one who had no freedom of action and whose person and services were wholly under the control of defendant and who was in a state of enforced compulsory service to the defendant. ${ }^{227}$

The facts of Jones's life spoke for themselves: an individual exercising her free will would simply not have countenanced such treatment. ${ }^{228}$

The chain of reasoning that led to a conviction in Ingalls differed greatly from that which led to peonage convictions less than a decade earlier. In the intervening period, complainants and their concerns, once primarily of physical restraint and imprisonment, encompassed the quality of their lives and the conditions of their work. The government's role too had shifted-from one of policing contracts to one of ensuring laborers their freedom.

\section{The Civil Rights SECTION's THIRTEENTH AMENDMENT PRACTICE IN HISTORICAL PERSPECTIVE}

The Civil Rights Section's use of the Thirteenth Amendment, and its shift away from contract and toward an emphasis on the legal, social, and economic trappings of involuntary servitude, allows a glimpse into the process of constructing a framework for civil rights in a time of doctrinal uncertainty. Emerging from, but rejecting, much of the Lochner constitutional universe, the Department of Justice experimented with a civil rights practice rooted in Reconstruction free labor ideology and shaped by mid-twentieth-century variations on the meanings of free labor. This part analyzes how the Section's practice reflected and reconfigured both the past on which it built and the present in which it operated. In that practice, it is possible to see a

227. Id. at 78 .

228. Until 1988, when the Supreme Court finally determined that objective indicia of force were required in order to make out a claim of involuntary servitude, United States v. Kozminski, 487 U.S. 931, 944 (1988) (noting that the prohibition against involuntary servitude extends to compulsion of labor "enforced by the use or threatened use of physical or legal coercion" but not "compulsion of labor by other means, such as psychological coercion"), the Department of Justice was free to prosecute, and courts to adjudicate, cases like Ingalls in which the conditions of life made it impossible for modern Americans to accept that a person exercising free will would choose to remain at such employment. See, e.g., United States v. Warren, 772 F.2d 827, 833 (11th Cir. 1985) (stating that "[v]arious forms of coercion may constitute a holding in involuntary servitude"); United States v. Bibbs, 564 F.2d 1165, 1167-68 (5th Cir. 1977) (same). But see United States v. Shackney, 333 F.2d 475, 486 (2d Cir. 1964) (reversing conviction where the only threat was deportation when there was no evidence that deportation was equivalent to, or worse than, imprisonment). 
unique, now forgotten, civil rights that targeted both racial and economic inequality.

\section{A. Reviving Free Labor for the Postwar Era}

When Frank Murphy established the Civil Rights Section, he was embarking, explicitly, on a project of creation. He was fashioning federal institutional authority for the protection of civil rights. ${ }^{229}$ What civil rights meant, however, as Part II demonstrated, was far from clear. In response to a mandate to create something out of nothing, Section lawyers looked to the past for authority and inspiration. The past offered authority and inspiration not only with regard to the general project of framing a civil rights enforcement agenda, but also with regard to the specific role labor rights would play in that agenda.

The centrality of labor to the Civil Rights Section's civil rights in the 1940s has two pedigrees. The first, older pedigree is rooted in Reconstruction. To many in the Reconstruction Congress, the Thirteenth Amendment not only ended slavery but also mandated "free labor," the flip side of slavery and servitude. ${ }^{230}$ Although no single

229. Arguably, the Reconstruction-era Freedmen's Bureau was the first federal authority for protecting civil rights. However, as mentioned supra note 92, its record on that score was quite mixed.

230. I cannot describe here the entire geneaology of "free labor." For discussions of the early delineation between free and unfree labor in England and the United States, see generally Robert J. Steinfeld, Coercion, Contract, and Free Labor in the Nineteenth CENTURY (2001) (reassessing the nature of wage labor during the nineteenth century in England and the United States leading to the birth of free wage labor); ROBERT J. STEINFELD, THE INVENTION OF FREE LABOR: THE EMPLOYMENT RELATION IN ENGLISH AND AMERICAN LAW AND CULTURE, 1350-1870, at 15-54 (1991) (contrasting early views of the master-servant relationship in English and American law); CHRISTOPHER L. TOMLINS, LAW, LABOR, AND IDEOLOGY IN THE EARLY AMERICAN REPUBLIC 232-92 (1993) (describing the law of master and servant in England and colonial America). Reconstruction free labor itself grew out of antebellum free labor ideology. For the classic treatment of the ideology prior to the Civil War, see ERIC Foner, Free SoIL, Free Labor, Free Men: The IdeOlogy of the Republican PARTY BEFORE THE CIVIL WAR 41 (1970), commenting that "[t]he most cherished values of the free labor outlook-economic development, social mobility, and political democracy-all appeared to be violated in the South." James McPherson describes antebellum free labor ideology as promoting a belief in the efficiency of free as opposed to slave labor, the dignity of manual work, improving education and social institutions, and diversifying the economy to benefit a broader caste. JAMES MCPherson, BATTLE CRY OF Freedom: The CIVIL WAR ERA 55 (1988). For an excellent discussion of laborers' changing conceptions of free labor in the postbellum period, see Forbath, supra note 72, at 801 (discussing labor's "anti-capitalist republicanism"). Specifically on the Thirteenth Amendment's free labor component, see James Gray Pope, Labor and the Constitution: From Abolition to Deindustrialization, 65 TEX. L. REV. 1071, 1096-1104 (1987) [hereinafter Pope, Labor and the Constitution] (commenting that the Thir- 
definition of free labor prevailed in the aftermath of the Civil War, many laborers and jurists alike saw the right to pursue one's calling in order to achieve property ownership and independence as central to the concept. ${ }^{231}$ Free labor also carried connotations of the dignity of labor, the autonomy of the individual, and the opportunity to find jobs, to advance economically, and to receive a just compensation for labor. ${ }^{232}$

In some ways, the Civil Rights Section's definition of "free labor" was quite similar to that of the Reconstruction era. For example, an early Civil Rights Section prosecution successfully brought an indictment where a photographer was prohibited from taking pictures of an election, claiming that he was prevented from pursuing his profession. ${ }^{233}$ Although the defendant ultimately was acquitted, the indictment survived a demurrer. ${ }^{234}$ The Fourteenth Amendment right underlying the Section's theory of the case resembles in no small way the butchers' claims in the Slaughter-House Cases themselves-a laborer's right to pursue his (and it certainly was his) ${ }^{235}$ occupation.

What made labor "free" during World War II nonetheless differed substantially from what made it free in the free labor ideology of Reconstruction and in the freedom-of-contract jurisprudence of the Lochner era. Explicitly eschewing the narrow definition of free labor embodied in Lochner-era substantive due process-that labor is free so long as freedom of contract in the most formal sense obtains $^{236}$ - the Section's second pedigree was rooted in mid-twentieth-

teenth Amendment should be interpreted to provide safeguards for labor protests); James Gray Pope, Labor's Constitution of Freedom, 106 YALE L.J. 941, 962-66 (1997) [hereinafter Pope, Labor's Constitution of Freedom] (describing Thirteenth Amendment arguments against the Kansas Industrial Court Act); Lea S. VanderVelde, The Labor Vision of the Thirteenth Amendment, 138 U. PA. L. REV. 437 (1989) (arguing that the congressional debates reveal a "free labor" vision of the amendment).

231. See Forbath, supra note 72, at 777 (discussing the concept of free labor embodied in Justice Field's opinion in the Slaughter-House Cases).

232. See VanderVelde, supra note 230, at 438.

233. Bixby, supra note 33, at 782 (discussing United States v. Cowan (E.D. La. 1940) (unreported)).

234. Id. at 782 n.265.

235. See Bradwell v. State, 83 U.S. 130, 141 (1872) (Bradley, J., concurring) (agreeing with the majority that the woman petitioner had no right to be licensed to practice law, but on the ground that a woman, unlike a man, does not have a privilege or immunity to "an independent career from that of her husband").

236. The Lochner-era free labor ideology itself grew out of Reconstruction ideas about free labor. See Forbath, supra note 72, at 782-87 (discussing the origins of liberty of contract in aboli- 
century law and politics. Layered on top of, and ultimately superceding, the Reconstruction conception of free labor was a conception based in the revolution in labor relations that the New Deal had effected. In a sense, it could be said that what Biddle and his staff were doing was taking the old, abolitionist, free labor ideology, reviving it for the twentieth century, and trying to make it constitutionally foundational.

As I discussed in Part I, from the very outset, the Civil Rights Section incorporated labor issues into its mandate for aggressive federal protection of civil rights. ${ }^{237}$ In addition to the unit's roots in 1930s labor issues, the personal background of Francis Biddle-the first attorney general to make substantial progress toward implementing some kind of federal authority over civil rights-meant a place for labor in the new Section's practice. When Biddle was chairman of the first National Labor Relations Board in 1934, he was frustrated by the weak enforcement apparatus of the National Recovery Act. ${ }^{238}$ The labor legislation of the late New Deal provided Biddle, as Attorney General, with precisely the kind of statutory authority he sought. Although in the Slaughter-House Cases $^{239}$ the Supreme Court had refused to place its imprimatur on the federal protection of labor rights, during World War II the Department of Justice depicted congressional action as having accomplished that goal at long last. While historians and legal scholars have debated whether the National Labor Relations Act (also known as the Wagner Act) affirmatively established the rights of workers, or merely instituted a regime for

tionism and Reconstruction thought and political and social conflict). See generally STANLEY, supra note 92 (maintaining that contract was a worldview that saw the ability to contract for wages as the antithesis of slavery).

237. See supra notes 14-27 and accompanying text.

238. Biddle had attempted to enforce the Board's findings, and to develop a body of law interpreting workers' rights under the National Recovery Act's section 7(a)—which protected the right to organize - but Homer Cummings's Justice Department had stymied his efforts on both counts. Biddle had been frustrated by the way in which the "paper rights" of the first Board raised hopes it could not fulfill. See Peter H. Irons, The New Deal Lawyers 225 (1982) ("Such paper rights raise hopes, but when they are shattered the reaction is far worse than if they had never been written in the statute books.") (quoting Biddle).

239. 83 U.S. $36(1872)$. 
preserving industrial peace that ultimately suppressed those rights, ${ }^{240}$ the Civil Rights Section attorneys harbored no such doubts. ${ }^{241}$

The "rights of individuals protected by federal law" now included collective bargaining under the Wagner Act, as well as other rights:

The right to wages under the Fair Labor Standards Act, rights under the Agricultural Adjustment Administration Act and the Social Security Act, rights to the use of housing projects constructed under the Lanham Act, rights of returning soldiers to reemployment under the Selective Service Act and, if implemented by appropriate legislation, the rights of minority groups (particularly Negroes) not to be discriminated against in employment-all these are rights now secured by Federal legislation directed against individual as well as against State interference. $^{242}$

Of all of these, the Wagner Act had the greatest impact: "[A]t long last, men who work can, and what is more[,] increasingly have organized themselves in to unions of their own choosing to enable them to bargain collectively." ${ }^{243}$ Consequently, Biddle and his Civil

240. See, e.g., Christopher Tomlins, The State and the Unions: Federal Labor Relations Policy and the Organized Labor Movement in America 1935-55, at 114 (1980) (arguing that the Wagner Act limited the autonomy and freedom of labor unions by bringing them under agency control); Melvyn Dubofsky, Legal Theory and Workers' Rights: A Historian's Critique, 4 INDUS. REL. L.J. 496, 496-97 (1981) (questioning the view of others, including Karl Klare and Staughton Lynd, that the Wagner Act and other federal labor laws strengthened employers and unions at the expense of workers by institutionalizing trade unionism and collective bargaining as the only sanctioned defenses for workers); Duncan Kennedy, Critical Labor Law Theory: A Comment, 4 INDUS. REL. L.J. 503, 506 (1981) (agreeing that the liberal rights theory provides an incoherent basis for understanding labor law); Karl E. Klare, Labor Law as Ideology: Toward a New Historiography of Collective Bargaining Law, 4 INDUS. REL. L.J. 450, 452 (1981) (arguing from critical labor law theory that labor law has served to place unions in the position of acting as protectors of industrial peace rather than protecting the rights and interests of workers); Staughton Lynd, Government Without Rights: The Labor Law Vision of Archibald Cox, 4 INDUS. REL. L.J. 483, 484 (1981) (arguing that the Supreme Court has favored an interpretation of the Wagner Act that stresses labor peace over workers' rights); Katherine Van Wezel Stone, The Post-War Paradigm in American Labor Law, 90 YALE L.J. 1509,1511 (1981) (arguing that the current model of industrial pluralism is faulty and that there is no equality of power in the work place between employers and unions).

241. In essence, Biddle argued, apparently with success, that the National Labor Relations Act had federalized a right previously considered protected by the states alone. For the view Biddle sought to overcome, see United States v. Moore, 129 F. 630, 631, 634-35 (N.D. Ala. 1904), which held that the right to organize was beyond doubt, but found that the right is protected only by the states and not by the federal government.

242. Biddle, supra note 33, at 20-21.

243. Id. at 31. The Section also saw its mandate as extending to the protection of "a labor organizer from the petty tyranny of local officials who have decided, federal law or no federal 
Rights Section Chief Victor Rotnem repeatedly cautioned that the "[c]onsistent violations and ignoring of the rights of collective bargaining, which is granted by the National Labor Relations Act," ${ }^{244}$ would not be tolerated. They declared that "[i]f the rights of labor are infringed through a violation of that statute, it is within the province of the Department of Justice to prosecute."245

Having defined the rights conferred on laborers through the New Deal statutes as "rights... secured by the... laws of the United States," ${ }^{246}$ the Civil Rights Section found the authority to prosecute using the Reconstruction era criminal civil rights statutes. One of those statutes, 18 U.S.C. $\S 51$ (now $\S 241$ ), allowed for criminal prosecutions of conspiracies to "injure, oppress, threaten or intimidate any citizen in the free exercise of any right or privilege secured by the Constitution or laws of the United States." ${ }^{247}$ After successfully prosecuting cases with this statutory combination, Rotnem stated, "Jurisdiction in these cases under Section 51 has been sustained and it can be exerted again whenever it is necessary to prevent the industrial unrest which is the result of constant violation of the rights of the workers." ${ }^{248} \mathrm{He}$ and his lawyers proudly described how the Section used that combination to quell intense labor strife in Kentucky and Georgia. ${ }^{249}$

As such cases suggest, the Civil Rights Section generally shared the New Deal legislation's apparent pro-labor bias. ${ }^{250}$ Rotnem frequently implied that the federal government was charged with protecting the rights of laborers because they were inherently subordinate to their employers absent governmental intervention. He de-

\footnotetext{
law, they will have no unions in their town." Rotnem, Civil Rights During War, supra note 9, at 411. Rotnem also discussed the illegality and danger of hate strikes by white workers against black employment or advancement, and found jurisdiction under the Fair Employment Practices Act and section 8 of the War Labor Disputes Act. Id. at 411-12. Coleman included among the responsibilities of the Section the civil rights statutes, federal election crimes, peonage and involuntary servitude or slavery, and the prosecution of criminal violations in conjunction with the various federal labor statutes. Coleman, supra note 9, at 417 n.6a.

244. Rotnem, Civil Rights During the War, supra note 9, at 411.

245. Rotnem, Labor's Civil Rights, supra note 9, at 21.

246. Id. at 19 .

247. 18 U.S.C. $\$ 51$ (current version at 18 U.S.C. $\$ 241$ (1994)).

248. Rotnem, Civil Rights During War, supra note 9, at 411.

249. Id.

250. But see supra note 240 (citing sources that argue that the Wagner Act did not have such a pro-labor bias).
} 
scribed using 18 U.S.C. $§ 51$ and the Fair Labor Standards Act "against greedy employers and unscrupulous union leaders who have conspired to deprive the workers of those rights." preted the National Labor Relations Act as unequivocally pro-labor: "This measure deals with subtler forms of economic pressure [that] ... can be directed against a worker by an employer who controls his job." ${ }^{, 252} \mathrm{He}$ thus saw the employer-employee relationship as one in which laborers were structurally the victims of everyday forms of coercion.

\section{B. The Convergence of the Thirteenth Amendment and the New Deal}

As a general matter, then, the Civil Rights Section drew on New Deal labor legislation ${ }^{253}$ to vindicate the federally protected rights of free labor. I now turn to an exploration of how this long-standing preoccupation with free labor, as shaped by the New Deal labor legislation, converged with the Department's expanding Thirteenth Amendment practice. This convergence resulted both from what the New Deal legislation accomplished and from what it failed to accomplish.

The New Deal's achievements seem to have affected the Section's Thirteenth Amendment practice in two ways. First, the mere existence of federal labor legislation, which represented a major step toward a national labor market, was reflected in the Civil Rights Section's aspirations for free labor with legally unrestricted mobility. Through its roots in the Commerce Clause, labor became an issue amenable to, and properly within, federal regulation. ${ }^{254}$ The New Deal revolutionized labor's place in the national economy and paved the way for unified labor standards. In Pollock v. Williams, ${ }^{255}$ Justice Jackson suggested the way in which the New Deal's promise of a nation-

251. Rotnem, Civil Rights During War, supra note 9, at 411.

252. Rotnem, Labor's Civil Rights, supra note 9, at 22-23.

253. National Labor Relations Act, ch. 372, 49 Stat. 449 (1935) (current version at 29 U.S.C. $\S \S 151-69$ (1994)); Fair Labor Standards Act, ch. 676, 52 Stat. 1060 (1938) (current version at 29 U.S.C. $\$$ 201-19 (1994)).

254. James Gray Pope argues, however, that the decision to root the Wagner Act in the Commerce Clause rather than the Thirteenth Amendment was harmful to the rights of labor. James Gray Pope, Roots of Lopez and Morrison: The Thirteenth Amendment Versus the Commerce Clause, 1921-1937 (2001) (unpublished manuscript, on file with the Duke Law Jour$n a l)$.

255. 322 U.S. 4 (1944). 
alized labor market might have affected contemporary meanings of involuntary servitude. He noted,

When the master can compel and the laborer cannot escape the obligation to go on, there is no power below to redress and no incentive above to relieve a harsh overlordship or unwholesome conditions of work. Resulting depression of working conditions and living standards affects not only the laborer under the system, but every other with whom his labor comes in competition. ${ }^{256}$

In light of such statements, Biddle interpreted Pollock and the other 1940s peonage cases as including within the mid-twentiethcentury meaning of involuntary servitude the creation of a national, unitary labor market unimpeded by state and local legal obstacles. As the Civil Rights Section moved toward that goal, it targeted the South in particular.

The South had in many respects operated as a separate labor market into the middle of the twentieth century. ${ }^{257}$ In 1938, for example, Franklin Roosevelt described the South as "the Nation's No. 1 economic problem" 258 and he called for the integration of the region into the national economy. ${ }^{259}$ Mobilization for the war effort began that process of integration. Maintaining the impermeability of the southern labor market, however, was precisely the goal of many state and local enticement, emigrant agent, hitchhiking, and vagrancy laws. Thus, when Biddle hoped to attack such laws, he was further expanding upon an understanding of free labor as only flourishing within a national labor market unencumbered by such legal restraints on mobility. ${ }^{260}$

256. Id. at 18 .

257. For a discussion of the existence of a separate southern labor market until World War II, see Gavin Wright, Old South, New South: Revolutions in the Southern ECONOMY SINCE THE CIVIL WAR 12 (1984) (stating that "southern labor markets were largely isolated from national and international labor markets").

258. Bruce J. Schulman, From Cotton Belt to Sunbelt: Federal Policy, ECONOmic Development, AND the Transformation of the South, 1938-1980, at 3 (1994) (quoting Roosevelt).

259. Id. at 48 .

260. As Brodie wrote in 1951,

The depressing effect of slave labor upon our society and economic system are properly the subjects of analyses by others than lawyers, but one could practically take judicial notice ... that the detriment suffered by the public as well as by the individual victim who is forced to work for another against his will is serious and substantial.

Brodie, supra note 9, at 398 (footnote omitted). 
Second, the particular rights enshrined in the New Deal labor legislation paralleled the Civil Rights Section's further expansion of the meaning of involuntary servitude during the late 1940s. When the Section broadened the definition of involuntary servitude to include "peonage-like" and abhorrent conditions, it targeted not only legal but also social and economic obstacles to free labor. In the context of the New Deal, this expansion can be read in two ways. On the one hand, conditions so bad and employment so isolated as to preclude the actual possibility of movement, organization, and collective bargaining actually could create involuntary servitude. In condemning restraints on labor's mobility, contemporary commentator Howard Devon Hamilton included "social and economic pressures" and "resistance to organization and movement of agricultural labor" among the obstacles that workers faced in violation of the Thirteenth Amendment's "objective of a system of completely free and voluntary labor throughout the United States." ${ }^{261}$ One way to counter such coercion was to ensure that agricultural labor could organize into unions, a right that had been denied such workers largely on racial grounds during the New Deal. Moreover, workers in states of such isolation and deprivation that they lacked "free will"- the time or energy to look for new employment, the proximity to such employment, interactions with others with whom organization might be possible-were apt to be poor candidates for the mechanisms of ensuring free labor. Working conditions themselves posed barriers to organization and bargaining and therefore posed barriers to the full and effective implementation of New Deal free labor principles.

Alternatively, the conditions of deprivation might have been seen not as the cause of a lack of free will, but as evidence of the same. As the Ingalls court indicated, a person choosing his or her employment obviously would not choose to work very long days under squalid and dehumanizing conditions. Hence, such employment relations must not be freely chosen. ${ }^{262}$ The absence of objective indicia of physical or legal force would thus become unnecessary where the conditions themselves reflected an overridden free will.

Whether the link was causal or symptomatic, the new baselines created by the New Deal for the conditions in which people worked paralleled expanding definitions of involuntary servitude, and the

261. Hamilton, supra note 36 , at 72 .

262. See supra note 228 and accompanying text. 
Section's civil rights practice used different legal tools to address various forms of coercion to work. Peonage and involuntary servitude represented more extreme forms of unfree labor, with redress through the Thirteenth Amendment. The abridgement of the rights to organize, to strike, or to receive decent wages constituted more mundane manifestations of legal and economic coercion; the Department of Justice combined New Deal labor legislation with Reconstruction civil rights statutes to ensure the integrity of those rights. The right to strike and the right to work for minimum wages under minimally acceptable conditions had become the means by which American workers would resist labor exploitation and protect themselves against the kind of involuntary servitude the Thirteenth Amendment prohibited. ${ }^{263}$ Whether those conditions were conceived of as a cause of such servitude, or as evidence of it, they represent a potentially very broad understanding of what constituted involuntary servitude, and, conversely, what it would take to create a truly free labor market. Thus,

263. Indeed, the recognition that the Thirteenth Amendment spoke to more than the most extreme forms of coerced labor extended beyond the confines of the Department of Justice. The 1947 Taft-Hartley amendment to the National Labor Relations Act, which restricted certain union economic weapons, was repeatedly referred to as a "slave labor bill" by unions and their supporters. E.g., IRVING RICHTER, LABOR's STRUgGLES, 1945-1950: A PARTICIPANT's VIEW 47 (1994). Moreover, during the years immediately following World War II, labor unions claimed repeatedly that the right to strike was rooted securely in the Thirteenth Amendment. Twice, district courts upheld that right, though both were reversed on appeal. See United States v. Petrillo, 68 F. Supp. 845, 849 (N.D. Ill. 1946) (noting that there is a Thirteenth Amendment right to refuse or discontinue employment), rev'd, 332 U.S. 1 (1947); France Packing Co. v. Dailey, 67 F. Supp. 841, 843 (E.D. Pa. 1946) ("Plaintiff appears unwilling to concede, lest it clash with the Constitutional prohibition against involuntary servitude, that [the War Labor Disputes Act] does not operate to prevent an employee from quitting his job."), rev'd, 166 F.2d 751 (3d Cir. 1948). One court even quoted the peonage case of Bailey v. Alabama, 219 U.S. 219, 241 (1911), in defense of the right to strike:

There is no doubt as to the constitutional right to discontinue an employment or to refuse such employment. The Thirteenth Amendment accomplishes the purpose "to make labor free, by prohibiting that control by which the personal service of one man is disposed of or coerced for another's benefit, which is the essence of involuntary servitude.

Petrillo, 68 F. Supp. at 849 (quoting Bailey, 219 U.S. at 241). In the postwar context, prohibitions on the right to strike came within many workers'-and at least a few jurists'-understanding of involuntary servitude. See, e.g., NLRB v. Nat'l Mar. Union, 175 F.2d 686 (2d Cir. 1949) (noting union claims to a Thirteenth Amendment right to strike); Printing Specialties \& Paper Converters Union v. LeBaron, 171 F.2d 331, 333 (9th Cir. 1948) (same); United States v. Int'l Union, UMW, 77 F. Supp. 563, 566 (D.D.C. 1948) (same); Pope, Labor and the Constitution, supra note 230, at 1073 (examining the constitutional underpinnings of the rights of labor to protest); Pope, Labor's Constitution of Freedom, supra note 230, at 963 (discussing organized labor's constitutional ideology); James Gray Pope, The First Amendment, the Thirteenth Amendment, and the Right to Organize in the Twenty-First Century, 51 RuTGERS L. REV. 941, 946 (1999) (same). 
when Biddle stated that the Thirteenth Amendment "guaranteed that there should not only be an end to slavery but that a system of completely free and voluntary labor should be maintained throughout the United States, ${ }^{264}$ he drew his image of that system primarily from the New Deal labor legislation.

When viewed in light of what the New Deal labor legislation failed to accomplish, the Civil Rights Section's use of the Thirteenth Amendment appears even more a product of its time. As scholars have noted, a political compromise Franklin Roosevelt had made with southern Dixiecrats left agricultural and domestic workers-the two occupational categories to which most African Americans in the South belonged-without redress in the New Deal labor legislation. ${ }^{265}$ They were excluded from the benefits of the National Labor Relations Act, the Fair Labor Standards Act, and other labor and social welfare legislation. Despite its basis in the Commerce Clause and its aspirations for comprehensive regulation and labor market unity, the New Deal's nationalizing project was, therefore, only partial.

The agricultural and domestic workers excluded from the New Deal legislation were precisely the workers the Department of Justice attempted to protect through the Thirteenth Amendment. In essence, the Civil Rights Section used the amendment to justify federal inter-

264. Biddle, supra note 33 , at 5 .

265. See DAvid ConRad, The Forgotten FArmers: The Story of SHARECroppers in THE NEW DEAL 205 (1965) (noting that "no guarantees were made that tenant farmers would share equitably in the government aid"); V.O. KEY, JR., SOUTHERn POLITICS IN STATE AND NATION 619-64 (1949) (discussing disenfranchisement of African Americans); SiTKOFF, supra note 121, at 34-57 (discussing African Americans' exclusion from New Deal legislation); NANCY Weiss, Farewell to the Party of Lincoln: Black Politics in the Age of FDR 163 (1983) (detailing how the labor industry left behind many black Americans under the compromise); Forbath, supra note 5, at 76 (discussing the "New Deal's notorious failure to enact a federal antilynching law" and the insistence of Dixiecrats that key provisions of New Deal legislation exclude the "main categories of southern labor"); Ira Katznelson et al., Limiting Liberalism: The Southern Veto in Congress, 1933-1950,108 POL. SCI. Q. 283, 292 (1993) (noting that the southern Democratic arm of Roosevelt's party "sought to restrict the political and economic capacities of two of the most important have-not groups in American life-African-Americans and the working class"); Marc Linder, Farm Workers and the Fair Labor Standards Act: Racial Discrimination in the New Deal, 65 TEX. L. REV. 1335, 1336 (1987) (arguing that Roosevelt and his allies, in compromising with southern congressmen to secure votes for New Deal legislation, settled for modifications that "preserved the social and racial plantation system in the south-a system resting on the subjugation of blacks"). The extent of President Roosevelt's involvement in the Civil Rights Section's civil rights agenda during the war is beyond the scope of this Article. For an account of Roosevelt's role, see ELLIFF, supra note 20, at 94-95 (arguing that Roosevelt played an important role in the creation of the Civil Rights Section). 
vention into employment relationships that Congress had deemed local, private, and off-limits to the federal government. ${ }^{266}$ Thus, the Civil Rights Section's Thirteenth Amendment practice can be read, in part, as extending the New Deal's expansion of the Commerce Clause even further. The Section's investigations in this area may not have successfully overturned the balance of power between agricultural and domestic employees and their employers, but they did point toward a civil rights law in which aspirations towards free labor in all sectors of the economy, including those explicitly left out of the New Deal, belonged. The Section showed itself willing to use the Thirteenth Amendment to enter into a whole host of previously sacred employment relationships to redress the balance of power within them. In this way, what the New Deal did not do appears to have had as profound an impact on the Section's use of the Thirteenth Amendment as what it actually achieved.

In excluding agricultural and domestic workers, the New Deal refused to take on the racial political economy of the South. That is precisely where the Section lawyers seemed headed as they enforced the Thirteenth Amendment. Such an attack would hardly have been foreign to the Thirteenth Amendment, which was born out of a struggle against African chattel slavery. ${ }^{267}$ That heritage, though reworked and reinterpreted, remained part of the Amendment's meaning even during World War II. As one observer commented in 1936, "Slavery was too integral a part of the social life of the South and too vital to the interests of certain classes to be suddenly eliminated by a mere constitutional amendment, although the amendment did make necessary the finding of new ways of perpetuating the Negro's enslave-

266. See generally SuZANNE METTLER, Dividing CitIZENS: GENDER AND FEDERALISM IN New Deal Public Policy xi-xii (1998) (describing how the New Deal excluded women and minorities from the new liberal, national support system and left them to the semi-feudalism of the states).

267. By focusing on the origins of the Thirteenth Amendment as involving race and labor, I do not mean to suggest that it did not also involve other aspects of social life. Other possible understandings of the origins of the Thirteenth Amendment not addressed here include control over one's body and reproduction, intrusion into and revolution within hierarchies of the family, and self-ownership. See, e.g., LAURA Edwards, Gendered STRIFE AND Confusion 24-65 (1997) (examining emancipation in the context of marriage and family structure); PATRICIA Williams, On Being the Object of Property, in THE AlChEMY OF RACE AND Rights 219 (1991) (discussing the role of personal will); Amar \& Widawsky, supra note 208, at 1360 (arguing that the Thirteenth Amendment can provide relief for children held in dehumanizing conditions). 
ment." ${ }^{268}$ Moreover, the post-Civil War South, even into the 1940s, retained a racial political economy based, at least in part, on the cheap, exploitable, controllable labor of African American men and women, particularly in the agricultural and domestic arenas. ${ }^{269}$ When African Americans complained to the Department of Justice about these conditions, that social context also wove its way into involuntary servitude prosecutions. As the Conclusion suggests, the fact that Thirteenth Amendment cases usually involved African American victims facing the most deeply oppressive working conditions allowed the Civil Rights Section to combat racial hierarchy and labor exploitation in a single cognizable legal claim.

\section{CONCLUSION: RACE, LABOR, AND A LOST CIVIL RIGHTS}

In 1952, political scientist Howard Devon Hamilton wrote optimistically in the National Bar Journal about the prospects for enforcing the Thirteenth Amendment. ${ }^{270} \mathrm{He}$ saw the 1948 revisions to the peonage statutes as improving the ability of the Department of Justice to enforce the law against "peonage-like conditions" and labor

268. Slavery Seventy Years After, Christian CENTURY, Dec. 9, 1936, at 1645 (quoted in DANIEL, supra note 106, at 174).

269. Most involuntary servitude took place in the South. See Bixby, supra note 33, at 781 (noting that almost all federal anti-peonage prosecutions were brought on behalf of black farm tenants against white farmers). However, the South did not remain unchanged for African Americans from Reconstruction to the 1940s. Large-scale migrations of African Americans to cities North and South, New Deal programs like the Agricultural Adjustment Act and the Tennessee Valley Authority, and World War II itself transformed much in the southern political economy. See generally SCHULMAN, supra note 258 (discussing the transformation of the southern economy from 1938 to 1980). On the migration of African Americans in the first half of the twentieth century, see generally James R. Grossman, LAND of Hope: CHICAGO, BLACK SOUTHERnERS, AND THE GREAT MigRation (1989) (exploring the Great Migration from the perspective of the participants); Nicholas Lemann, The Promised Land: The Great Black Migration and How It Changed America (1991) (following the Great Migration from Mississippi to Chicago to Washington and back); THE GREAT MigRATION IN HISTORICAL Perspective: New Dimensions of Race, Class, And Gender (Joe William Trotter, Jr., ed., 1991) (interpreting recent scholarship on the Great Migration into Virginia, the Midwest, and California from a historical perspective); JoE William TrotTer, JR., Black MilwaUkeE: The MAKING OF AN Industrial Proletariat 1915-45 (1985) (examining the African American experience in Milwaukee as an instance of "proletarianization"). On the effect of the Great Depression and New Deal on African Americans, see generally JACQUELINE JONES, LABOR OF LOVE, LABOR OF SORROW: Black WOMEN, WORK, AND THE FAMILY FROM SLAVERY TO THE PRESENT 196-231 (1985); SITKOFF, supra note 121; WEISS, supra note 265.

270. Hamilton, supra note 36 , at 73-77. 
exploitation. ${ }^{271}$ He noted that the Workers Defense League and the National Farm Labor Union were actively publicizing and pursuing cases of forced labor. ${ }^{272}$ Commenting on the Supreme Court's 1944 opinion in Pollock v. Williams, he wrote, "One can only conclude that the Supreme Court, zealous to protect civil rights, particularly of the weak, has placed freedom from involuntary servitude in the same class as the 'fundamental liberties' of the First Amendment, against which any impinging statute is denied the usual presumption of constitutionality."

Hamilton was not alone in his enthusiasm. Into the 1950s, legal scholars commented on the need for a more robust Thirteenth Amendment jurisprudence. ${ }^{274}$ At this time, the future of civil rights doctrine remained uncertain. The President's 1947 Commission on Civil Rights, for example, divided rights into the "safety and security of the person" (involuntary servitude and peonage, police brutality, lynching), "citizenship and its privileges," "freedom of conscience and expression," and "equality of opportunity." treatise on political and civil rights, Emerson and Haber still emphasized the category of "the security of the person," which contained roughly the same rights the President's Commission included in its "safety and security of the person." 276 The first chapter of the treatise covered harms in that category, ${ }^{277}$ and the final chapter discussed "discrimination." ${ }^{278}$ Each approach to civil rights had its own place, its own arena, even into the 1950 s. $^{279}$

\footnotetext{
271. Id. at 71 .

272. Id.

273. Id. at 54 .

274. See, e.g., Brodie, supra note 9, at 388 (noting the need to update the peonage laws); tenBroek, Consummation to Abolition, supra note 99, at 171 (noting the "grand" but unfulfilled historical promise of the Thirteenth Amendment).

275. PRESIDENT'S COMMITTEE ON CIVIL RIghts, supra note 137, at 6-9.

276. Thomas I. Emerson \& David Haber, Political and Civil Rights in the UNITED STATES 1 (1952).

277. See id. at 1 ("Chapter I. The Right to Security of the Person").

278. See id. at 993 ("Chapter IX. Discrimination").

279. The 1958 edition of Emerson and Haber retained the same basic structure, with the security of the person and discrimination in their own sections. See THOMAS I. EMERSON \& David Haber, Political and Civil Rights in the United States (2d ed. 1958). By the 1967 edition, however, the entire second volume of the treatise comprised materials on "discrimination," and the security of the person constituted one chapter under that heading. See Thomas I. EMERSON \& DAVID HABER, Political AND CIVIL Rights IN THE UNITED STATES (3d ed. 1967).
} 
The year Hamilton concluded his study of the Thirteenth Amendment, however, was the last year in which that amendment garnered much discussion, much aspiration, or much promise as a basis for civil rights in the postwar United States. ${ }^{280}$ During the 1950s and the decades that followed, the Equal Protection Clause of the Fourteenth Amendment would come to dominate legal understandings of civil rights. In the context of race, that clause has become increasingly synonymous with a focus on racial classification without reference to substantive inequality. ${ }^{281}$ Because of this centrality of equal protection to civil rights in the last half of the twentieth century, constitutional historians generally have viewed the history of the NAACP's litigation strategy - which eventually focused on freeing

280. Beginning with Jones v. Alfred H. Mayer Co., 392 U.S. 409 (1968), the Thirteenth Amendment did experience a kind of renaissance as the constitutional basis for civil rights legislation first passed in the Civil Rights Act of 1866. The Thirteenth Amendment that the Jones Court seemed to rediscover, however, bore no resemblance, and did not originate in, the racelabor practice of the Civil Rights Section in the 1940s. Relying on the "badges and incidents" theory of the Thirteenth Amendment initially set out in the Civil Rights Cases, Jones and its progeny treated the amendment as a Fourteenth Amendment prohibition on racial classification without a state action requirement. See, e.g., Patterson v. McLean Credit Union, 485 U.S. 617, 619 (1988) (holding that the Thirteenth Amendment empowers Congress to enact legislation banning segregation in private secondary schools); Runyon v. McCrary, 427 U.S. 160, 178 (1976) (same); see also Robert C. Post \& Reva B. Siegel, Equal Protection by Law: Federal Antidiscrimination Legislation After Morrison and Kimel, 110 YALE L.J. 441, 495-96 (2000) (discussing the use of the Thirteenth Amendment to address racial classifications in the late 1960s). I do not mean to suggest that the Department of Justice has not continued to prosecute peonage and involuntary servitude cases since the 1950s. It clearly has. See, e.g., United States v. Kozminski, 487 U.S. 931, 953 (1988) (overturning convictions because of a jury instruction that encompassed means of coercion other than physical force or legal coercion); United States v. Warren, 772 F.2d 827, 833 (11th Cir. 1985) (stating that "[v]arious forms of coercion may constitute a holding in involuntary servitude"); United States v. Bibbs, 564 F.2d 1165, 1167-68 (5th Cir. 1977) (same); United States v. Shackney, 333 F.2d 475, 486 (2d Cir. 1964) (reversing conviction where the threat was of deportation rather than involuntary servitude). Those cases, however, do not significantly shape the dominant meaning of "civil rights" in either legal or popular discourse.

281. Many legal scholars view Brown itself as offering the possibility of a civil rights jurisprudence with a concern for substantive equality. They locate the shift to the classification regime, and the quashing of a possibility for substantive equality, in Washington v. Davis, 426 U.S. 229, 239-48 (1976) (holding that a law or other official act is not unconstitutional if it has a racially disproportionate impact unless the purpose is racially discriminatory). I view Brown more as a historical than a doctrinal moment in the dominance of the equal protection framework. For examples of a pure racial classification approach, see Adarand Constructors, Inc. v. Pena, 515 U.S. 200, 235 (1995) (requiring strict scrutiny analysis for all race-based classifications); and City of Richmond v. J.A. Croson Co., 488 U.S. 469, 494 (1989) (holding that the "standard of review under the Equal Protection Clause is not dependent on the race of those burdened or benefited by a particular classification"). 
the Equal Protection Clause from Plessy v. Ferguson-as providing a full account of the origins of contemporary civil rights law. ${ }^{282}$

The Thirteenth Amendment's doctrinal eclipse, however, should not translate into its historical evisceration. This Article shows how incomplete the familiar story is, and how the strong association of "civil rights" with "racial classification" was not inevitable. I have argued that, contrary to constitutional scholarship that virtually ignores the period, developments in civil rights between 1939 and 1954 are crucial to a complete understanding of subsequent civil rights jurisprudence. ${ }^{283}$ Although the war brought civil rights concerns to the forefront of national attention, the disarray of legal doctrine following the Supreme Court's decisions in the late New Deal era meant that the legal meaning of the term was confused and ambiguous.

The Civil Rights Section of the Department of Justice looked to a variety of pasts, some more recent than others, for inspiration, for constitutional authority, and for the language and frameworks with which to build a federal program to protect civil rights. The practice that Civil Rights Section lawyers built during the 1940s resulted from a myriad of overlapping motivations: the pressures of unions and civil libertarians; the demands of African Americans in organized protest organizations and on their own; Biddle's early experiences with the National Labor Relations Board, as a concomitant of the Great Depression-era construction of a new set of fundamental rights; the legal requirements of federal jurisdiction and state action (or the use of authorities without a state action requirement) the Civil Rights lawyers had to meet in order to enforce civil rights; and the Civil Rights Section lawyers' hope that they could dampen charges of American hypocrisy and the effectiveness of enemy propaganda by protecting African Americans. As a result of these disparate pressures, the Department of Justice lawyers used the Constitution to provide a measure of justice and protection to those (mostly poor, black, and southern) to whom Congress had refused to extend the protection of federal labor law.

282. I address the development of the NAACP's approach to labor-related civil rights in Risa Goluboff, Law, Labor, and Race: The NAACP, Involuntary Servitude, and the Development of a Consistent Legal Strategy (2001) (unpublished manuscript, on file with author).

283. I explore the uncertainties of civil rights between 1939 and 1954 further in my dissertation, Risa L. Goluboff, The Destruction and Creation of American Constitutional Law: Practicing Civil Rights, 1939-1954 (forthcoming Ph.D dissertation, Princeton University) (on file with author). 
The fact that the Section's civil rights practice during the 1940s and early 1950s was attentive to the rights of African Americans and the rights of laborers, and melded these two kinds of concerns, highlights the limits of the dominant narrative of postwar civil rights law. As they experimented with ways of fulfilling Frank Murphy's federal civil rights mandate, the attorneys of the Civil Rights Section practiced a civil rights law very different from the one with which we are now familiar. In particular, the critical place of labor within that civil rights law looks foreign to us today. In legal doctrine, scholarship, and education, "labor law" and what has become known as "antidiscrimination law" occupy separate spaces. When they do intersect, it is in the realm of employment discrimination, in which the workplace is simply one arena in which racial classification and discrimination occur.

In the civil rights of the 1940s Civil Rights Section, however, that was not the case. Attention to the rights of laborers-a category including both racial minorities and whites-focused the Section on the challenges of subsistence working conditions, wages, and bargaining power. That attention, combined with political pressures to attend to the rights of African Americans, meant that race and labor coexisted as two parts of the Section's mandate. They combined in a myriad of ways. Most pertinent here is the combination that resulted from the fact that the people who often worked in the most oppressive conditions, which were least conducive to organization and regulation, were African Americans. This means that the cases the Section prosecuted often had poor, working African Americans as victims, complainants, and shapers of the meaning of involuntary servitude and civil rights.

The Thirteenth Amendment is a large part of this lost story. In tying that amendment to a racial conception of civil rights, the Section did not displace its free labor origins. Rather, its lawyers revived those origins in the context of New Deal labor legislation and included them in its practice of civil rights. Use of the Thirteenth Amendment, with its historical nexus of race and labor and its midcentury application to the plight of largely African American workers, reinforced the shared place of race and labor in the Section's civil rights practice.

At mid-century, then, one concept of "civil rights" found in the Civil Rights Section's practice had the potential to encompass both labor and racial concerns within its ambit. That mandate did not ap- 
pear to be as anomalous to mid-century federal officials as it does to us today. ${ }^{284}$ The Section took labor matters seriously, publicized them along with its other civil rights activities, and helped foster a definition of civil rights that included rather than disdained labor freedom alongside racial equality. During a period in which the meaning of postwar civil rights remained undefined, involuntary servitude prosecutions helped galvanize a civil rights practice infused with economic concerns. ${ }^{285}$ That practice, rich with possibilities for generating alternative conceptions of civil rights, has since largely disappeared.

284. But see CARR, supra note 13, at 189 (describing these responsibilities as "miscellaneous" and detracting from the main goals of the Civil Rights Section).

285. See O. John Rogge, Justice and Civil Liberties, 25 A.B.A. J. 1030, 1031 (1939) (describing actions taken by the Section to protect the rights of those with low economic status). One wartime commentator who wrote about democracy generally (but not involuntary servitude in particular) also suggested a substantive view of civil rights in the mainstream Bill of Rights Review. He wrote that "the two dominant desires to which all else is subordinate" for Americans "as a group" were "that each member of the group shall receive at least a decent, minimum subsistence, and ... that each member of the group shall have the maximum individual freedom or liberty that is consistent with the achievement of the first objective and with a like freedom for every other member of the group." Frey, supra note 38, at 165. 